\title{
Conversion of technical lignins to functional materials with retained polymeric properties
}

\author{
Yasuyuki Matsushita
}

Received: 29 November 2014 / Accepted: 8 January 2015/Published online: 4 April 2015

(C) The Japan Wood Research Society 2015

\begin{abstract}
A significant amount of technical lignins is produced in the pulp and paper industries. However, most technical lignins are burned for thermal recycling and a few percent are used as materials, such as lignosulfonate as a dispersant. Native lignin has a highly complex structure and is susceptible to structural variations depending on the pulping process, thus hindering the effective utilization of lignins. The procedures used to convert lignins into functional materials include depolymerization to monomeric fragments followed by re-building to functional materials, and chemical modifications to generate functional polymers with retained polymeric properties. In this paper, the latter is disserted. The characteristics of technical lignins, which include kraft lignin, lignosulfonate, and organosolv lignin, and their conversion to functional materials such as polyesters, polyethers, polyurethanes, etc. and the applications of lignin-based materials in some fields are discussed.
\end{abstract}

Keywords Technical lignin · Functional material · Lignin-based materials

\section{Introduction}

Almost 170 years ago, a French chemist named Anselme Payen treated wood with concentrated nitric acid and

This review article is published to coincide with the 60th anniversary of the Japan Wood Research Society.

\section{Y. Matsushita $(\bowtie)$}

Graduate School of Bioagricultural Sciences, Nagoya

University, Furo-cho Chikusa-ku, Nagoya, Aichi 464-8601, Japan

e-mail: ysmatsu@agr.nagoya-u.ac.jp caustic soda to yield two different products, namely "cellulose" and an "incrusting material". The latter possessed a high carbon content and was termed "lignin", which was derived from the Latin word lignum meaning wood. After that, Kason studied the composition of lignosulfonates and postulated that lignin is a macromolecular substance composed of coniferyl alcohol. He also developed many valuable procedures for lignin analysis that are still widely used today. In 1930, Erdtman studied the oxidative dimerization of phenols and concluded that lignin must be formed from $\alpha, \beta$-unsaturated coniferyl alcohols via enzymatic dehydrogenation. Freudenberg and co-workers conducted comprehensive studies during 1940-1970 and stated that the polymerization of lignin precursors is indeed carried out in this manner and leads to carbon-carbon and alkyl-aryl ether linkages. The structure of lignin is highly complicated, and many researchers continue to investigate its structure today $[1,2]$.

As mentioned above, the chemical structure of lignin consists of three basic phenylpropane units, which originate from $p$-coumaryl, coniferyl, and sinapyl alcohols. During biological lignification, the phenylpropane units are connected via radical coupling reactions to form a complex three-dimensional macromolecule [3]. The major linkage types include $\beta-O-4, \beta-5, \beta-\beta$, and 5-5 linkages among others. The lignin composition and content vary according to species. For example, softwood lignin is primarily composed of coniferyl alcohol with trace amounts of $p$-coumaryl alcohol, whereas hardwood lignin is made of coniferyl and sinapyl alcohols with trace amounts of $p$-coumaryl alcohol. Furthermore, grass lignin is composed of $p$-coumaryl, coniferyl, and sinapyl alcohols.

A large amount of biomass is present on the earth, and biochemicals derived from biomass are expected to reduce 
atmospheric carbon dioxide levels. Polysaccharides in biomass, such as cellulose, have been used in many fields including in the production of pulp, paper, fibers, and filters, while only a small amount of lignin is utilized to produce commercial materials, even though they are the main component of biomass. It is estimated that there is about $3 \times 10^{11}$ metric tons of lignin and $2 \times 10^{10}$ tons is biosynthesized per year [4]. As such, it is necessary to determine effective ways to utilize lignin.

Nowadays, technical lignins can be generated as a byproduct of the pulping process. The major commercial lignins include kraft lignin and lignosulfonate. Other lignins such as organosolv lignins are obtained from the pulping process using organic solvents such as ethanol, acetic acid, and formic acid among others. The structure of lignin differs depending on the isolation process. The functional groups and molecular weight also vary among the different types of lignins. The functional groups, type of phenylpropane units, linkage between structural units, and molecular weight distributions restrict the applications of lignin as an industrial material. Table 1 details the characterization of lignins.

The typical procedures carried out prior to the utilization of technical lignins can be categorized into two groups: (1) depolymerization to monomeric small fragments followed by re-building into functional materials, and (2) chemical modification to functional polymers with retained polymeric properties. While both approaches have advantages and disadvantages, energy consumption may be lower in the latter system than in the former system. In this paper, the latter method and applications of functionalized lignin-based polymers in a variety of fields as well as the characteristics of technical lignins are discussed.

\section{Characterization of technical lignins}

\section{Kraft lignin}

The sulfur (1-2\%) in kraft lignin occurs as elemental and organically bound sulfur [22, 23] and some extractives may also exist in kraft lignin [24, 25]. During the kraft pulping process, lignin is subjected to depolymerization. Simultaneously, the depolymerized lignin fragments are re-polymerized, thus resulting in a lower reactivity and thereby limiting their potential for further condensation without the use of a cross-linking agent. Some representative structures are shown in Fig. 1 [26, 27]. The important reactions in kraft pulping have been investigated using model compounds (Fig. 2) [28, 29] and are described below.

\section{Degradation reactions}

- Formation of quinone methide intermediate by loss of anion from the $\mathrm{C} \alpha$-position of the phenolate ion.

- Addition of hydrogen sulfide ion in $\mathrm{C} \alpha$-position leading to re-aromatization.

- Sulfidolitic cleavage of phenolic $\beta$-aryl ether bond by hydrogen sulfide.

- Alkali-promoted elimination of terminal $\gamma$-hydroxymethyl group of phenolic $\beta$-aryl ether resulting in the formation of alkali-stable vinyl ether.

- Sulfidolytic cleave of methyl-aryl ether bond leading to the generation of catechol structure and methanethiol.

\section{Condensation reactions}

- Reaction of quinone methide intermediate with other nuclei, involving the 5-position of ring.

Table 1 The characterization of technical lignins

\begin{tabular}{|c|c|c|c|c|c|c|c|}
\hline & \multirow[t]{2}{*}{ Species } & \multicolumn{2}{|c|}{ Hydroxyl group } & \multicolumn{3}{|c|}{ Molecular weight } & \multirow[t]{2}{*}{ References } \\
\hline & & $\begin{array}{l}\text { Total } \\
(\mathrm{mmol} / \mathrm{g})^{\mathrm{a}}\end{array}$ & $\begin{array}{l}\text { Phenolic } \\
(\mathrm{mmol} / \mathrm{g})^{\mathrm{a}}\end{array}$ & $M_{\mathrm{w}}\left(\times 10^{3}\right)$ & $M_{\mathrm{n}}\left(\times 10^{3}\right)$ & $M_{\mathrm{w}} / M_{\mathrm{n}}$ & \\
\hline \multirow[t]{2}{*}{ Kraft lignin } & Softwood & $6.5-8.6$ & $2.7-3.5$ & $1.1-45.7$ & $0.5-7.7$ & $2.2-13.4$ & {$[5-11]$} \\
\hline & Hardwood & $6.5-8.4$ & $4.3-4.7$ & $2.4-4.8$ & $0.4-1.3$ & $1.8-12.0$ & {$[5,8,12]$} \\
\hline \multirow[t]{2}{*}{ Lignosulfonate } & Softwood & $-{ }^{\mathrm{b}}$ & $1.2-1.9$ & $10.5-60.2$ & $2.7-6.5$ & $6.7-22.3$ & {$[6,11,13]$} \\
\hline & Hardwood & $-{ }^{\mathrm{b}}$ & $1.4-1.5$ & $6.9-7.8$ & $2.4-4.6$ & $1.7-3.0$ & {$[11,13-15]$} \\
\hline \multirow[t]{2}{*}{ Ogranosolv lignin (ethanol) } & Softwood & $6.3-10$ & $2.7-3.1$ & $2.9-5.4$ & $1.8-3.1$ & $1.6-1.8$ & {$[16,17]$} \\
\hline & Hardwood & 5.7 & 2.8 & $2.0-2.6$ & $1.3-1.6$ & $1.5-1.6$ & {$[12,17]$} \\
\hline (Formic acid) & Miscanthus & $3.7-4.9$ & $1.6-2.4$ & 2.8 & 1.1 & 2.5 & {$[6,7,18]$} \\
\hline (Acetic acid) & Hardwood & $5.5-5.8$ & $3.5-4.0$ & 0.9 & $-{ }^{\mathrm{b}}$ & $-{ }^{\mathrm{b}}$ & {$[19,20]$} \\
\hline (Acetic acid/formic acid) & Wheat straw & 3.4 & 1.0 & 2.2 & 1.6 & 1.3 & [21] \\
\hline
\end{tabular}

${ }^{a}$ Some data were modified unit from original references

b Not available 


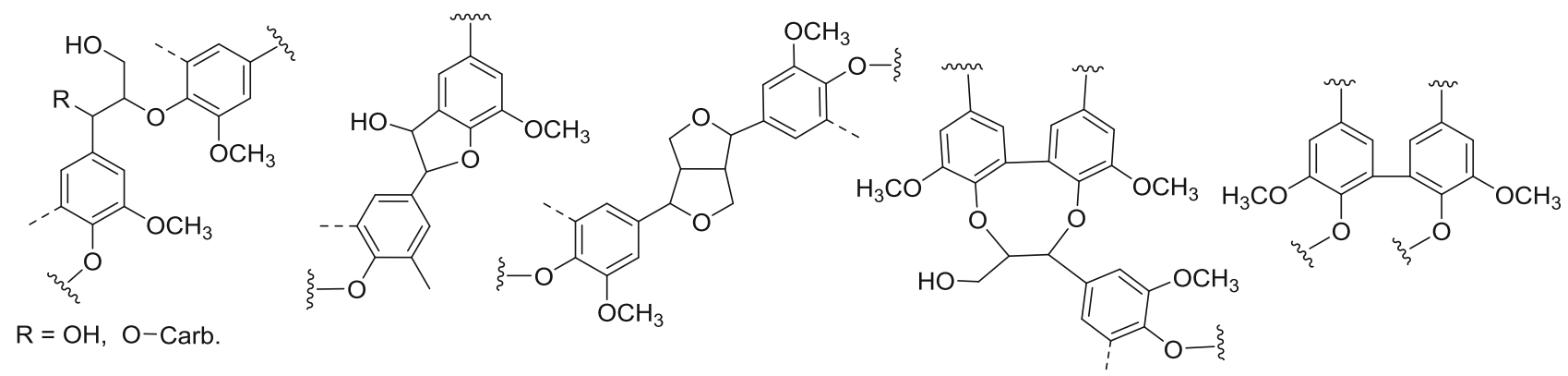<smiles>COc1cc(C(O)C2(CO)Oc3ccc(C)cc3-c3cc(C)ccc3O2)cc(C)c1OC</smiles><smiles>CCOc1c(OC)cc([Al])cc1Oc1c(C)cc(I)cc1OC</smiles><smiles>CCOc1c(Cc2cc(Cl)cc(OC)c2OC)cc(C)cc1OC</smiles><smiles>COc1cc(/C=C\Oc2c(C)cc(C)cc2OC)cc(C)c1OC</smiles><smiles>COc1cc(/C=C/Br)cc(C)c1OC</smiles><smiles>COc1cc(/C=C/CO)cc(C)c1OC</smiles><smiles>CCOc1c(C)cc(CC(O)C(=O)O)cc1OC</smiles><smiles>COc1cc(C(O)C(O)CO)cc(C)c1OC</smiles><smiles>CCOc1c(C)cc(C(c2cc(C)cc(OC)c2O)C(C)C)cc1C</smiles><smiles>CCOc1ccc(OC)cc1Cc1cc(CC(CO)C(CO)Cc2cc(OC)c(OC)c(OC)c2)cc(OC)c1</smiles>

Fig. 1 Partial structures of kraft lignin [26, 27]

- Reaction of formaldehyde, generated by elimination of terminal $\gamma$-hydroxymethyl group, with aromatic nucleus resulting in diphenylmethane structure.

Enol ethers are formed during the kraft pulping process via formaldehyde elimination from $\beta-O-4$-containing structures in the reverse aldol reaction through the cleavage of the $\mathrm{C} \beta-\mathrm{C} \gamma$ bond. The structures of the enol ethers are detected in kraft lignin due to their stability under alkaline conditions. However, the number of enol ethers in kraft lignin is quite small as compared to the numbers observed in experiments using model compounds [25, 30, 31]. Using two-dimensional nuclear magnetic resonance spectroscopy (2D NMR), it was revealed that the possibility for the formation of diarylmethane structures is limited [25, 30]. The authors implied that this was due to the limited formaldehyde elimination. On the other hand, some reports have detailed the elimination of the $\gamma$-hydroxymethyl group as one of the major reactions during kraft pulping. Terashima et al. [32] investigated kraft pulping using radio tracer experiments. Using $\gamma_{-}{ }^{14} \mathrm{C}$ labeled lignin, they concluded that a large portion of the eliminated $\gamma$-carbon fragments were converted to water-soluble compounds with a low molecular weight. As such, much of the eliminated $\gamma$-carbon fragments may combine with low molecular weight compounds, which may lead to solubilization. A small portion of the $\gamma$-carbon fragments formed formaldehyde may participate in the formation of insoluble diarylmethane in precipitated kraft lignin.

During kraft pulping, cellulose and hemicellulose are degraded and some of the degraded compounds are modified to carboxylic acids such as glycolic acid and lactic acid. The total amount of carboxylic acids corresponds to about $20 \%$ of the wood weight in black liquor. To obtain kraft lignin, an acid precipitation or enzyme treatment is typically carried out. However, the complete removal of the carbohydrate derivatives is difficult, resulting in contamination [33]. The $\alpha$-hydroxy carboxylic acids formed by aldol condensation reactions between degraded aldehyde-containing lignin fragments and keto or aldol type carbohydrate-derived fragments, followed by benzylic acid rearrangement have been observed (Fig. 3) [29, 33-36]. Lignin-carbohydrate (LC) ether bond formation between lignins and carbohydrates at the $\beta$ position was suggested based on reactions with non-phenolic model compounds [37]. 


\section{Degradation reactions}

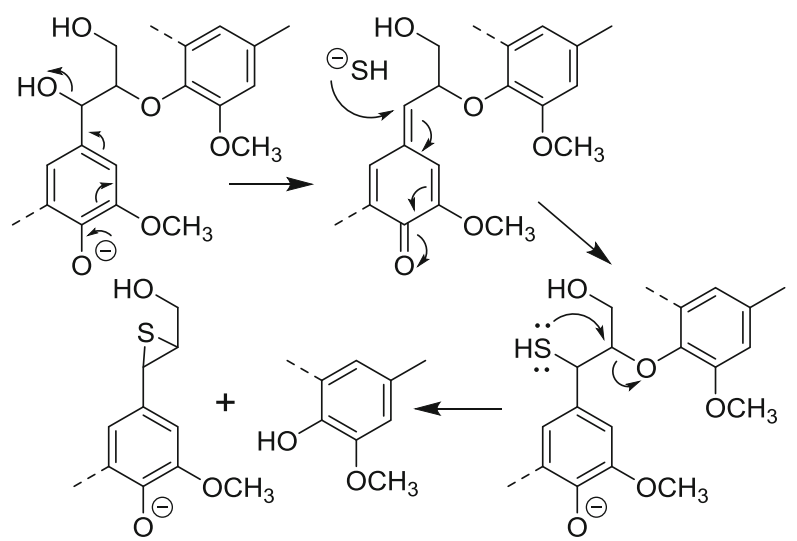<smiles>COc1cc([C@@H](O)C(CO)Oc2c(OC)cc(/C=C\Oc3c(C)cc(C)cc3OC)cc2OC)cc(C)c1OC</smiles><smiles>COc1c(C)cc(C)cc1OCCC(O)C(C)O</smiles>

\section{Condensation reactions}<smiles>COC1=CC(CCCCc2ccc(C)cc2OC)C=C(C)C1=O</smiles><smiles>COc1cc(C(C)c2cc(C)cc(OC)c2O)cc(C)c1[O-]</smiles>

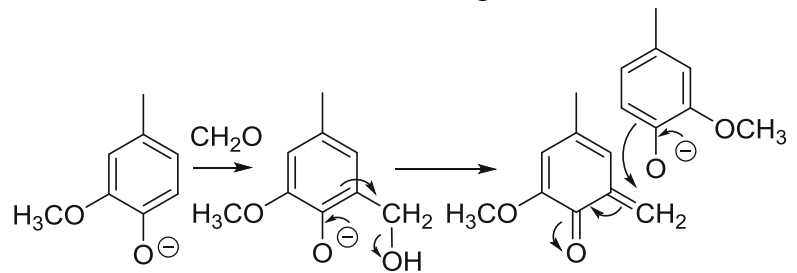<smiles>COc1cc(C)cc(Cc2cc(C)cc(OC)c2[O-])c1[O-]</smiles>

Fig. 2 Typical reactions of lignin during kraft pulping process [28, 29]

The possibility of the homolytic degradation of the $\beta-O-4$ linkage of quinone methide moieties, especially $\beta$-syringyl types, was proposed under alkaline cooking
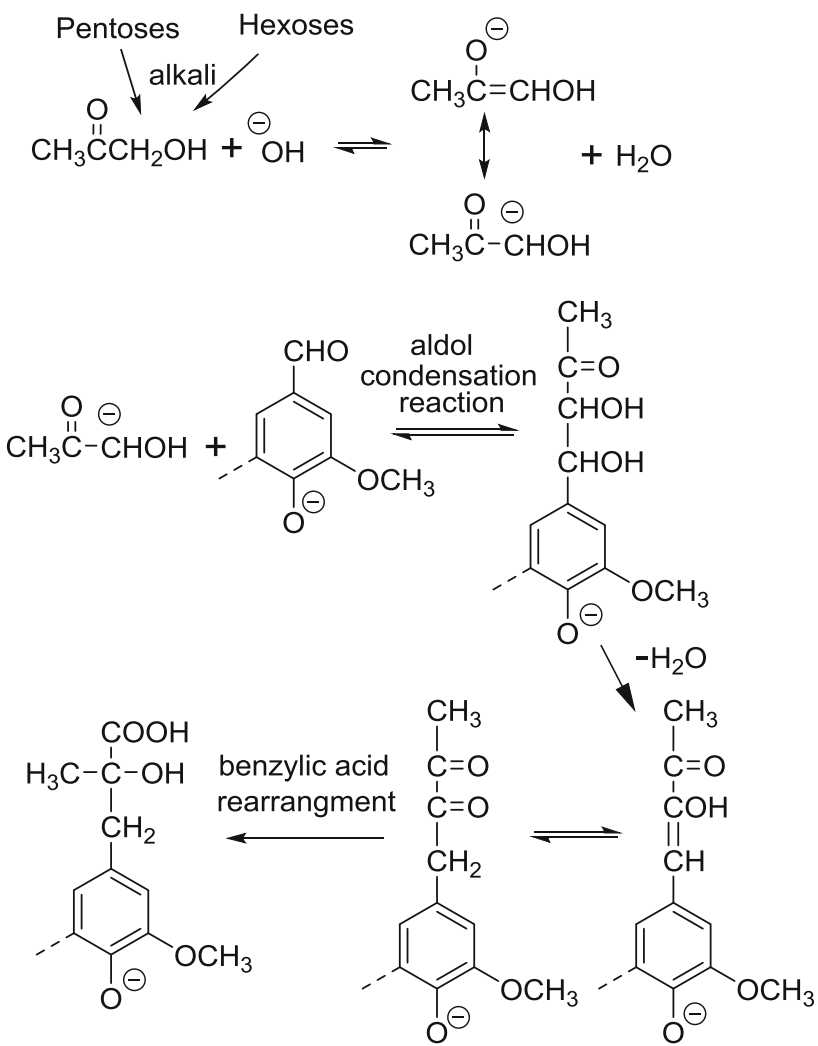

Fig. 3 Reactions between degraded lignin fragments and carbohydrate-derived fragments during kraft pulping process [36]

conditions followed by the generation of coupling products such as resinols [38-41]. Coniferyl alcohol was observed in kraft black liquor [42]. Notably, coniferyl alcohol was polymerized with another degraded fragment of lignin [43].

The $\beta-O-4$ linkage content in black liquor was reported to decrease with increased cooking times, but was still observed at the end of the cooking period. Taneda et al. [44] reported that non-phenolic $\beta-O-4$ structures with hydroxyl groups in the $\alpha$-position could be degraded easily via kraft cooking. However, structures with a benzyl ether bond between carbohydrates showed high resistance to degradation. Such structures cannot form quinone methide moieties during cooking, thus leading to the restricted cleavage of the $\beta-O-4$ linkage. The $\beta-O-4$ linkage can be cleaved via participation of $\gamma$-hydroxyl groups, but the reaction rate is slow. Thus, the remaining $\beta-O-4$ linkages could be of the non-phenolic type with a benzyl ether bond [25].

In some studies, kraft lignin was subjected to fractionation prior to analysis. Lindberg et al. [45] fractionated kraft lignin by soxhlet extraction with organic solvents. Mörck et al. [23] separated softwood kraft lignin into five fractions via successive extractions with organic solvents. They reported that the polydispersity in the high molecular weight fraction was higher than that in the low molecular 
weight fraction. The high molecular weight fraction contained a considerable amount of carbohydrates $(8.7 \%)$. The methoxy and acidic group contents decreased with increased molecular weights. According to the ${ }^{13} \mathrm{C}$ NMR analysis, a saturated side chain was present, which indicated that reductive reactions were likely occurring during the kraft cooking. The saturated moieties were prevalent in the low molecular weight fraction. The number of $\beta-O-4$ linkages increased with increasing molecular weight. Phenylcoumaran ( $\beta-5)$ and pinoresinol ( $\beta-\beta)$, likely in their etherified forms, were also found in the high or low molecular weight fractions. $\alpha$-ketones, $\alpha$-aldehydes, and o-quinone structures were also detected via ${ }^{13} \mathrm{C}$ NMR. Furthermore, $\gamma$-ethers were proposed based on 2D NMR $[25,46]$.

\section{Lignosulfonate}

Typically, delignification occurs under acidic or neutral conditions during sulfite cooking. The reaction mechanism and the structure of lignosulfonate have been studied using model compounds [47-51]. The delignification reaction mechanism during sulfite pulping is as follows (Fig. 4):

1. Quinone methide intermediates are formed by loss of the hydroxyl group or cleavage of the $\alpha$-ether linkage. Under neutral conditions, the reaction proceeds with phenolic-type substrates, while under acidic conditions it proceeds with phenolic and non-phenolic-type substrates via a benzylic cation.

2. Sulfite ions add to the quinone methide intermediates at the $\alpha$-position to produce benzyl sulfonic acid units.

3. When the sulfonation reaction proceeds under neutral conditions, the electron withdrawing effect of the $\alpha$ sulfonic acid group of the $\beta-O-4$ moiety facilitates the nucleophilic attack by the sulfite on the $\beta$-carbon atom resulting in the sulfitolytic cleavage of the $\beta$-aryl ether bond.

4. Under acidic conditions, a condensation reaction occurs between the benzylic carbon and the carbon in the 6-position of another nuclei owing to the benzylic cation.

Upon introduction of the sulfonic acid groups, lignin becomes hydrophilic, and exhibits enhanced water solubility. The number of sulfonated groups in lignosulfonate varies from 0.4 to 0.7 per phenyl propane unit $[11,52]$.

Based on an investigation using radio isotope labeling, Araki et al. [53] concluded that the changes in lignin during the sulfite pulping process were smaller than those that occurred in the kraft pulping process.

According to the aforementioned reaction mechanism of sulfite pulping, the putative lignosulfonate structure based

\section{Acidic condition}

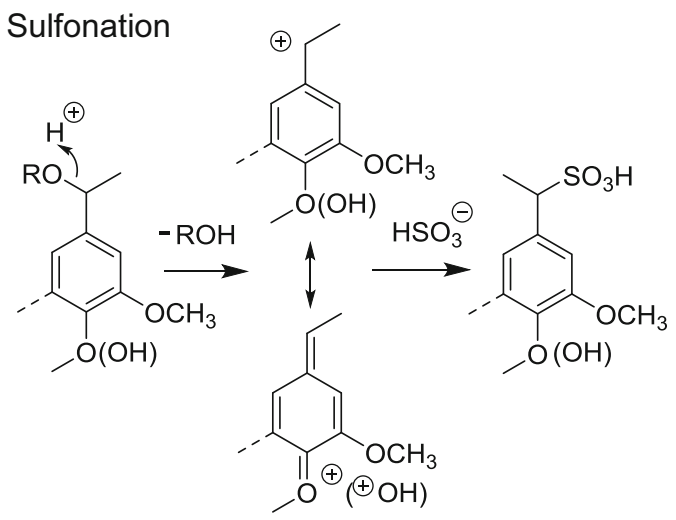<smiles>COc1cc(C)c(OC)c(OC)c1</smiles>

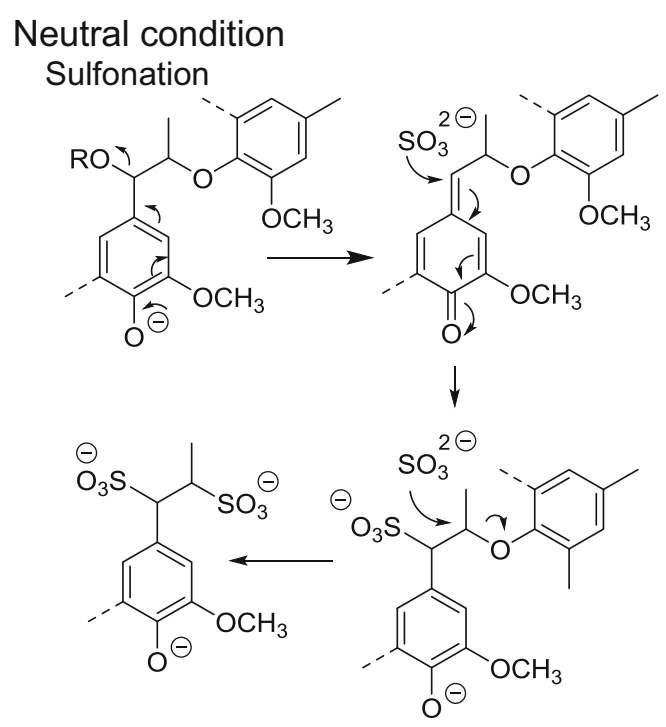

Fig. 4 Typical reactions of lignin during sulfite pulping process [47-51]

on Sakakibara's lignin model [54] is subjected to sulfite pulping as shown in Fig. 5.

NMR analysis of lignosulfonate has been also reported. Lutnaes et al. [55] characterized fifteen monomeric and seven dimeric sulfonated model compounds by NMR. However, the NMR study of lignosulfonate is little [52].

The overall structure and shape of lignosulfonate is not well-established. Gardon and Mason [56] were the first to 


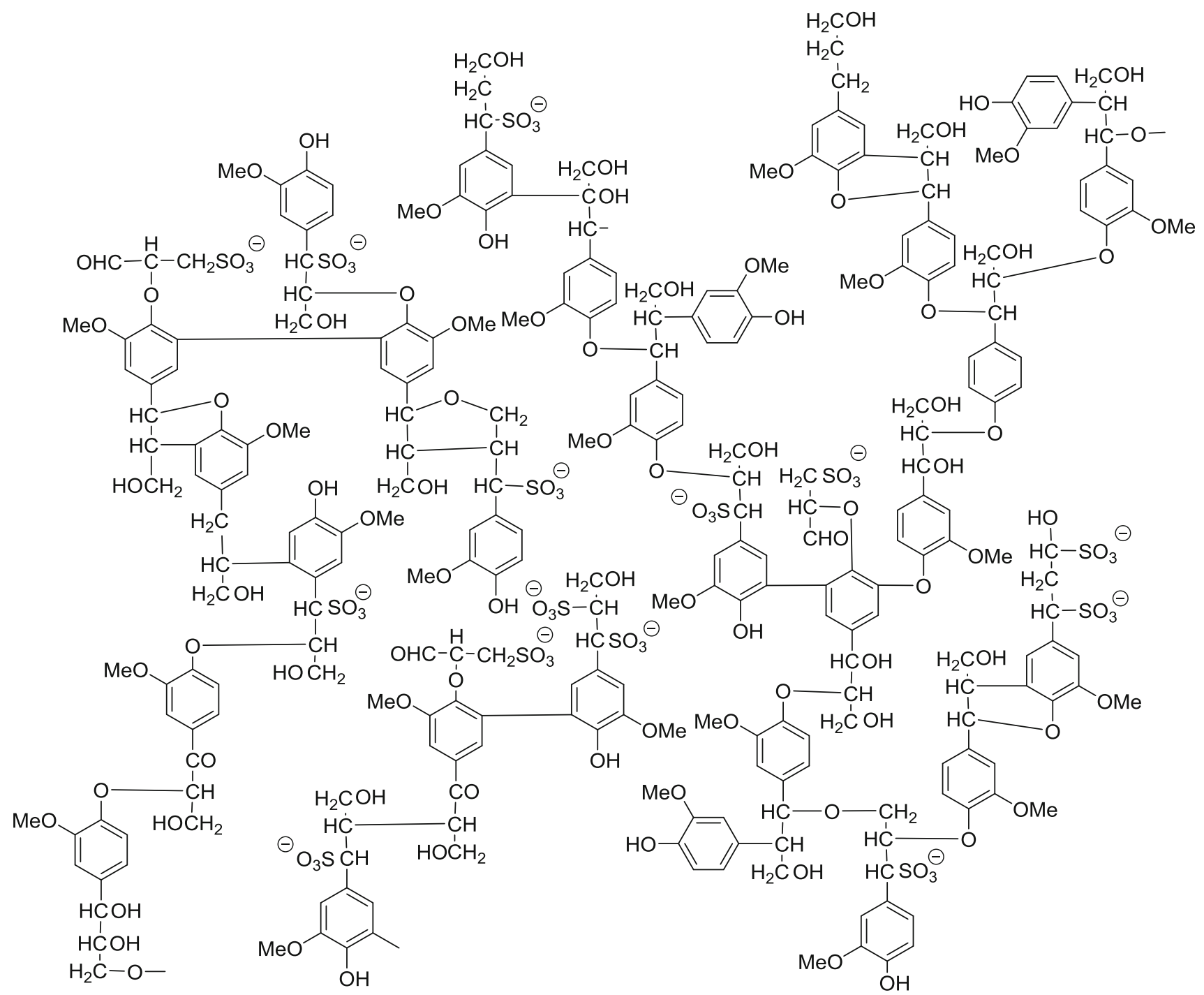

Fig. 5 Putative structure of softwood lignosulfonate inferred from sakakibara lignin model [54]

report that lignosulfonates behave as flexible polyelectrolytes. They concluded that the degree of molecular branching in high molecular weight lignosulfonates was greater than that in the low molecular weight fractions. In neutral aqueous solutions, the sulfonate groups are ionized and lignosulfonates possess an overall negative charge. According to previous studies, lignosulfonate is believed to form microgels in solution [57, 58]. Recently, Kontturi et al. [59] showed that lignosulfonate exhibits a conformational change from a compact sphere to an unwinding coil under electric fields. This transformation does not occur if the lignosulfonate is in a gel with cross-links. To resolve this contradiction, Myrvold [60] proposed a randomly branched polyelectrolyte structure, in which the sulfonate groups were less prevalent in the backbone than in the side chains, suggesting that the backbone was more hydrophobic. In aqueous solutions, polymeric lignosulfonate molecules coil to form a spherical shape with the sulfonate groups on the surface. As such, the randomly branched polyelectrolyte model suitably explains the solution behavior of the macromolecule.

\section{Organosolv lignin}

Organosolv lignins can be obtained from the black liquor of biomass using organic solvents such as ethanol, acetic acid, and formic acid among others. Organosolv lignins can be recovered by precipitation by adjusting conditions such as temperature, $\mathrm{pH}$, and concentration. Generally, organosolv lignins have high purity and with solubility in organic solvents as well as a low molecular weight and a low polydispersity. They are insoluble in water due to their 
hydrophobicity. Organosolv lignins do not contain sulfur, which is a significant advantage for environment applications.

The Alcell process is a typical organosolv process using aqueous ethanol, which was developed by Repap Enterprises and was commercialized in 1989 [61]. The Alcell process involves organosolv pulping with delignification using aqueous ethanol as the cooking liquor. The $\mathrm{pH}$ of the cooking liquor is relatively low, owing to the generation of organic acids from hemicellulose. As such, the cooking process is carried out under acidic conditions. The protolignin can be subjected to condensation reactions between the $\alpha$-position of the side chain and the 6-position of another aromatic ring $[62,63]$. Liu et al. studied the condensed phenolic groups in solubilized and residual lignin during the Alcell process by ${ }^{31} \mathrm{P}$ NMR. Accordingly, the condensed phenolic $\mathrm{OH}$ content of Alcell lignin (solubilized lignin) was lower than that of kraft lignin because some of the protolignin was condensed during the Alcell process, which led to issues with solubility and pulp retention [64].

Acetic acid has been employed to obtain acetosolv lignins from hardwood, softwood, and grass. In the presence of a catalytic amount of a strong acid such as sulfuric acid, extensive and selective delignification can be accomplished $[20,65-70]$. The delignification mechanism and the structure of acetic acid lignin have been investigated using model compounds [71-73]. The reactions include acetylation of hydroxyl groups, acidolysis, hydrolysis, and homolytic cleavage of $\beta$-aryl ethers, as well as elimination of the hydroxyl group at the $\gamma$-position as formaldehyde. Inter- and intra-molecular condensations also occur during acetic acid pulping.

In the early 1900s, Pauly developed a delignification process using formic and acetic acid, and Freudenberg et al. used formic acid as a wood pulping solvent [74]. Recently, Biolignin ${ }^{\mathrm{TM}}$ was produced by the CIMV process from wheat straw by cooking it with a mixture of acetic acid, formic acid, and water on a pilot scale [21]. Biolignin $^{\mathrm{TM}}$ was characterized by a low molecular weight, low polydispersity, and numerous free hydroxyl groups.

\section{Functionalization of technical lignins}

Major conversion reactions including phenolic resination, esterification, etherification, urethanization, and radical polymerization will be discussed in this section (Fig. 6).

Phenolic resination

Lignin contains phenolic $\mathrm{OH}$, making it an interesting alternative to phenol in the production of phenol-formaldehyde

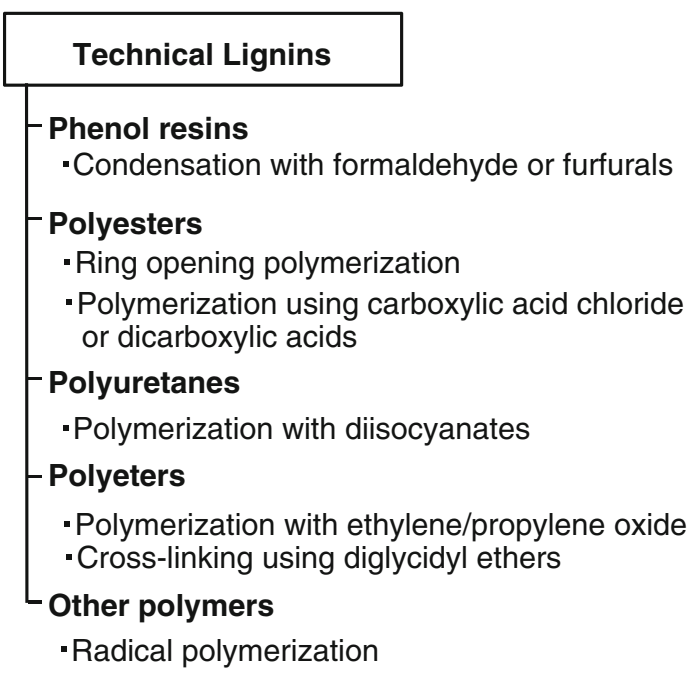

Fig. 6 Functionalization of technical lignins as polymers

(PF) resins [75]. In the 1970s, after 6 years of basic research and development, the Finnish Pulp and Paper Research Institute developed a lignin-based adhesive called Karatex. Accordingly, the high molecular weight fraction of lignosulfonate or kraft lignin could be used to displace at least $40 \%$, and on occasion as much as $70 \%$, of phenol in $\mathrm{PF}$ resin $[75,76]$. The commercial plant for the production of Karatex was established in Finland and had an annual capacity of 2000 tons of purified kraft lignin.

Formaldehyde reacts with lignins in the presence of alkali species, both by substitution at the free 5 -position in the phenolic nuclei via a Lederer-Manasse reaction, and by the Tollens reaction on the side chains bearing carbonyl groups, which results in the introduction of a hydroxymethyl group. Kraft lignin has an extremely low reactivity, as it was estimated that there are only $0.5 \mathrm{~mol}$ per $\mathrm{OCH}_{3}$ reactive sites on pine kraft lignin available for reaction with formaldehyde [77]. Studies conducted by Marton and co-workers revealed that about 30 and 10 hydroxymethyl groups are introduced by the Lederer-Manasse reaction and by the Tollens reaction, respectively [77]. Zhao et al. reported a kinetic study regarding the hydroxymethylation of pine kraft lignin. They concluded that about $0.36 \mathrm{~mol}$ of $\mathrm{CH}_{2} \mathrm{OH} / \mathrm{C} 9$ units was introduced under the optimal reaction conditions, of which about $0.33 \mathrm{~mol}$ was introduced on the C-5 of guaiacyl moieties via the Lederer-Manasse reaction [78].

The reactivity of kraft lignin towards formaldehyde depends on the wood species, owing to the difference in methoxy group substitution and the number of condensed linkages between the phenyl propane units. The use of softwood lignin is more advantageous in the production of PF resins containing lignin than that of hardwood lignin because hardwood lignin contains syringyl units, which results in a reduced number of free 5-position in the 
phenolic moieties. However, some studies have reported the use of kraft lignin from Eucalyptus [79, 80], alkali bagasse lignin [81, 82], kraft lignin from bamboo [79], and straw [83] for production PF resins that contained lignins.

Lignosulfonate can be also used to produce lignin-containing PF resins. Alonso et al. [13] evaluated the reactivity of various lignosulfonates towards formaldehyde. Softwood lignosulfonates exhibited higher reactivity towards formaldehyde than hardwood lignosulfonates, and softwood ammonium lignosulfonate showed the highest reactivity. Peng et al. studied the kinetics of lignin hydroxymethylation. They reported that lignosulfonates could be hydroxymethylated at a lower temperature than phenol owing to the lower activation energy of lignosulfonates [84]. Ultra-filtrated high molecular weight lignosulfonate (LS) can be used to manufacture insulation boards based on mineral wool, as it forms an adhesive when combined with phenol resin [85]. Notably, LS/PF resins with compositions ranging from 10/90 to 30/70 have appropriate technical and commercial properties.

Organosolv lignin can be used for PF resin. Ethanol lignin, which is obtained from ethanol-water pulping, can be applied in the production of adhesives. Ayla reported that a resin composed of $90 \%$ ethanol lignin (isolated from beech or pine wood) and $10 \%$ phenol led to boiling proof bond according to the German Standards [86]. Formacell and Acetocolv lignins from Eucalyptus can be used in PF resins [19, 87, 88]. Sano and Ichikawa prepared PF resins containing cresol lignin, which was obtained from solvolytic pulping of hardwood chips with aqueous cresols. They showed that at least $90 \%$ of the phenol resins could be replaced by the cresol lignin [89]. During solvolysis using a cresol-water system, a significant amount of cresol (10-30 \% cresol) was introduced onto lignin, resulting in an improved reactivity towards formaldehyde. This system showed comparable performance to commercial PF resins, however, cresol lignin could not be commercially available. Upon addition of resorcinol to cresol lignin-phenol resins, moderate-temperature setting adhesives (room temperature setting followed by hot press) could be prepared. Sano et al. [90] also reported moderate-temperature setting lignin-based adhesives based on resorcinol and cresol lignin.

In general, the adhesive bonding strength of PF resins containing lignin is comparable to that of commercial PF resins. However, unmodified lignin is not viable for commercial adhesive applications due to the requirement of a high hot-press temperature and long curing time [91].

To overcome this disadvantage, modifications to the chemical structure of lignin have been attempted. Numerous reports have been published regarding the preparation of modified lignins for applications as PF adhesives [9193].
Notably, phenolation has been shown to increase the reactivity of PF resins towards formaldehyde. Specifically, under acidic conditions, phenols were introduced at the $\alpha$ position of lignin [94-100]. Phenolation can also occur under alkaline conditions, and the reaction mechanism is similar to that of condensation that occurs during kraft cooking [101, 102]. Kobayashi et al. [103-105] subjected kraft lignin to phenolation and observed a $2-2.5$ times higher reactivity than that of unmodified kraft lignin.

Another potential modification is demethylation. Shashi et al. [106] used dichromate in the presence of acetic acid to decrease the amount of methoxy groups in kraft lignin from 11.9 to $2.8 \%$ and to increase the amount of phenolic hydroxyl groups from 2.4 to $11.2 \%$. Hayashi et al. [107] reported the demethylation of lignosulfonate using $\mathrm{K}_{2} \mathrm{Cr}_{2} \mathrm{O}_{7}$. An adhesive can be manufactured using demethylated softwood kraft lignin with increased reactivity towards formaldehyde [108]. Through this pretreatment, the replacement of the demethylated lignin by phenol increased to $90 \%$ [109]. Demethylation is an effective way to improve the qualities of lignin-containing PF resins. However, $\mathrm{Cr}$ is toxic. Lignin can be demethylated and degraded by treatment with alkali species at high temperatures [110-113]. Pine kraft lignin was subjected to pretreatment using a $10 \%$ solution of sodium hydroxide at $125^{\circ} \mathrm{C}$ for $1 \mathrm{~h}$ to demethylate the guaiacyl unit, resulting in the generation of a catechol unit. The pretreated kraft lignin was used to manufacture a PF resin. The bonding ability of the PF resin in which $40 \%$ of the phenol moieties was replaced was comparable to that of commercial PF resins [114].

Partially depolymerization has also been reported as an effective route towards highly reactive lignin species. Pine ethanol lignin was degraded in aqueous ethanol with catalysts, $\mathrm{Ru} / \gamma-\mathrm{Al}_{2} \mathrm{O}_{3}$ and Ni/activated carbon, at $>300{ }^{\circ} \mathrm{C}$ under an $\mathrm{H}_{2}$ atmosphere [115]. The molecular weight of the ethanol lignin decreased by about half during the treatment, and the phenol replacement in the PF resin was $75 \%$. According to ${ }^{1} \mathrm{H}-\mathrm{NMR}$ analysis, hydrogenolytic/hydrolytic cleavage of the aryl-alkyl ether, i.e., the $\beta-O-4$ linkage, occurred to generate new phenolic and secondary hydroxyl groups during the degradation.

Shinatani et al. [116, 117] investigated the use of a hydroxymethylated softwood kraft lignin-phenol resin (HLP resin) to prepare moderate-temperature and cold setting wood adhesives (with the setting and pressing at room temperature). They reported that the tensile shear strength of 3-ply plywood based on HLP resin reached $24.3 \mathrm{kgf} / \mathrm{cm}^{2}$ in the dry test and $17.3 \mathrm{kgf} / \mathrm{cm}^{2}$ in the wet test, both of which were comparable values to those of commercial PF resins. The molecular weight $\left(M_{\mathrm{n}}\right)$ of the ether insoluble fraction of the prepared HLP resin was 4000-6000. 
Phenolic foams are made from phenol and formaldehyde with appropriate combinations of flowing agents. They have excellent fire-resistant properties and do not produce harmful smoke upon exposure to flames, while rigid plastic insulation materials such as polystyrene, polyurethane, and polyethylene do produce smoke. Moreover, they also possess other outstanding characteristics such as thermal insulation, heat resistance, chemical resistance, weatherability, and workability. Phenolic foams are widely used in a broad range of applications including as building materials, in automobiles, and in aircraft [118]. For example, Hu et al. [119, 120] utilized phenolated lignosufonate in phenolic foams as a replacement for phenol. They showed that the produced foams had a lower density, superior toughness, and excellent thermal insulation as compared to those of foams obtained from conventional resol resins, and thus were useful for practical applications. A $30 \mathrm{wt} \%$ reduction in the molecular weight was accomplished via replacement of phenol with oxidatively degraded lignosulfonate [120].

Several procedures have been developed for the production of phenolic adhesives and resins without the use of formaldehyde. It is well-known that starch can be hydrolyzed into monosaccharides, which can be further dehydrated into furfural derivatives. Thus, hydrolysates could be used in phenolic resins [121]. Zhang et al. reported the replacement of formaldehyde with hydrolyzed starch using liquefied phenolated lignosulfonate to produce a PF resin [122] with acceptable physicochemical specifications, thermal resistance, and mechanical properties as compared to the PF resin.

\section{Esterification}

Typically, three procedures are applied to produce ligninbased polyesters: ring opening reactions with cyclic esters, condensation polymerization using carboxylic acid chloride, and dehydration polymerization with dicarboxylic acids.

Oliveira and Glasser [123] reacted $\varepsilon$-caprolactone with hydroxypropylated softwood kraft lignin to yield ligninbased polyesters. This polyester formed a star-like shape with hydroxypropylated lignin as the core of the star and polycaprolactone as the hard arm segments. They estimated the average number of arms per core ranged between 2 and 7 , and the $T_{\mathrm{m}}$ increased with the arm length as the degree of polymerization of $\varepsilon$-caprolactone increased to 50 . Hirose et al. [124] prepared alcoholysis lignin-based polyesters using $\varepsilon$-caprolactone and investigated the thermal degradation behavior of the polyesters using thermogravimetryFourier transform infrared spectroscopy (TG-FTIR). The mass residue at $500{ }^{\circ} \mathrm{C}$ decreased with increasing $\varepsilon$ caprolactone/hydroxyl group ratios. The thermal degradation of the polycaprolactone chain began at $430{ }^{\circ} \mathrm{C}$.
Matsushita et al. [125] prepared lignin-based polyesters using alkali hydrothermalized acid hydrolysis lignin with $\varepsilon$-caprolactone. Following the alkali hydrothermal reaction, acid hydrolysis lignin could be dissolved in water at a neutral $\mathrm{pH}$ owing to the introduction of carboxylic acid moieties [126]. Based on differential scanning calorimetry, swelling tests, and dynamic mechanical thermal analysis, the obtained polyester formed a three-dimensional network via interactions between the hydroxyl and carboxyl groups of the lignin and polycaprolactone chain, and did not dissolve in organic solvents or melt at high temperatures. In addition to $\varepsilon$-caprolactone, lactide also has been used for copolymerization with lignin. Chung et al. [127] produced a lignin-polylactide polyester in a metal- and solvent-free system using triazabicyclodecene as a catalyst.

Guo et al. [128] prepared lignin-based polyesters from softwood kraft lignin and dicarboxylic acid chlorides, sebacoyl chloride, and terephthaloyl chloride via condensation polymerization in organic solvents. The obtained polyesters were mostly cross-linked polyesters owing to participation of the aliphatic and phenolic hydroxyl groups as well as the dicarboxylic acid chlorides. Moreover, they were thermally stable up to $200{ }^{\circ} \mathrm{C}$ under a nitrogen atmosphere. Guo et al. also investigated the use of polyethylene glycol as a co-monomer and solvent for kraft lignin. However, the obtained polyesters exhibited a low $T_{\mathrm{g}}$ and formed elastomers at room temperature. The lignin content was only $35 \%$ [129]. Recently, Luong et al. [130] produced lignin-based polyesters using kraft lignin and sebacoyl chloride.

Several dehydration polymerization procedures using dicarboxylic acids have been proposed. Fang et al. [131] synthesized a dicarboxyl acid by the dimerization of unsaturated fatty acids derived from natural oils. The dimeric acid was applied in the coesterification with enzymatically hydrolyzed, steam-exploded cornstalk lignin. This dicarboxylic acid had a long alkyl chain, which made the co-ester flexible. The lignin content reached approximately $60 \%$. Hardwood kraft lignin could be reacted with carboxytelechelic polybutadiene to produce lignin-based polyesters. The use of high molecular weight kraft lignin or pre-polymerized kraft lignin using formaldehyde facilitated the preparation of free standing films. An ionic linkage between the lignin and carboxytelechelic polybutadiene was formed, in addition to covalent linkages, which had an effect on the properties of the polyesters [132]. To improve the thermal-mechanical properties, dehydration copolymerization of lignin with hyperbranched prepolymers containing carboxylic acid moieties, which were synthesized from triethanolamine, tris(hydroxymethyl)aminomethane, and dicarbonic acid by melt polycondensation, was proposed [133, 134].

Esterification of lignin using $\varepsilon$-caprolactone, maleic anhydride, and succinic anhydride can be carried out to 
increase the reactivity for the production of lignin-based epoxy resins [135-137] and polyurethanes [138].

\section{Etherification}

The primary procedures utilized for the preparation of lignin-based polyethers include the following: (1) polymerization using ethylene oxide and propylene oxide, (2) polymerization using epichlorohydrin, (3) cross-linking using diglycidyl ethers, and (4) solvolysis of wood chips with ethylene glycol to introduce ethylene glycol chains into lignin. In most cases, a combination of the aforementioned procedures is utilized.

The aromatic moieties within lignin improve the thermal and mechanical properties of epoxy resins. Hofmann and Glasser [139] prepared epoxy resins from steam explosion lignin by hydroxyalkylation using propylene oxide and ethylene oxide. Subsequently, the reaction mixture was treated with epichlorohydrin and was cured with m-phenylene diamine for cross-linking. The modulus and ultimate strength of the prepared epoxy resin increased with increasing lignin contents, while the ultimate strain decreased. The strength of the resins was comparable to those of the diglycidyl ether of bisphenol A-based resins.

The phenolic hydroxyl groups in lignin allow for the partial substitution of bisphenols in epoxy resins. Ligninepoxy resins were synthesized by the poly-addition reaction between epichorohydrine and lignosulfonate in an alkali medium to obtain lignin-epoxy prepolymers, which were used in the cross-liking reaction with phthalic anhydride or diaminodiphenylmethane [140]. The resulting films absorbed atmospheric humidity to a small extent. The shear strengths of wood samples glued with the ligninbased epoxy resin were above $20 \mathrm{kgf} / \mathrm{cm}^{2}$, which was comparable to those of commercial epoxy adhesives.

To improve the reactivity of lignin, phenolation was applied. Lignosulfonate was submitted to phenolation using phenol [141, 142], beta-naphtol [141], and bisphenol [141] to increase the phenolic hydroxyl group content and was then epoxidized using epichlorohydrin.

It is reported that organosolv lignin [143-146] and kraft lignin [147-149] could be modified upon reaction with several epoxylated polyethylene glycol (PEG) derivatives. To reduce the cost of preparation, the modification was also carried out using kraft cooking black liquors, since the alkali species were retained and acted as catalysts [149]. Uraki et al. [143] produced amphiphilic lignin derivatives from acetic acid lignin (AL) via reaction with polyethylene diglycidyl ethers (PE) and lignin-based gels by increasing the lignin concentration in the same reaction [144]. The gel with a PE/AL ratio of 0.57 exhibited unique swelling properties against aqueous ethanol. It swelled with increasing ethanol concentrations, and reached the maximal swollen state at 50-60\%. Nonaka et al. [147] reported the viscoelastic properties of kraft lignin-based epoxy resins using PE cured with dialiphatic amines. The peak temperature of the loss modulus increased with increasing kraft lignin contents and decreasing ethylene oxide chains of the PEs. Those resins exhibited very broad relaxations due to the glass transition, thus they could be applied as adhesives or damping materials to reduce the emitted noise and vibrations. Lin synthesized a non-ionic dispersant by grafting PEG on softwood kraft lignin using epichlorohydrin [150].

The direct grafting of ethylene glycol chains into lignin from woody biomass was carried out by solvolysis using ethylene glycol. Kubo et al. [151] proposed a biomass conversion system using ethylene carbonate/ethylene glycol. Specifically, softwood meal was submitted to solvolysis at $150{ }^{\circ} \mathrm{C}$ to dissolve the starting materials. Following extraction with water, the lignin fraction was obtained as a water-insoluble solid. Ethylene glycol chains were introduced into the lignin primarily on the hydroxyl groups at the $\alpha$ and $\gamma$-positions. The average degree of polymerization (DP) was approximately 3.0. Instead of ethylene glycol, polyethylene glycol can be used. Lin et al. [152, 153] produced PEG-lignin using polyethylene glycol 400 (PEG 400).

\section{Urethanization}

It is well-known that polyurethane has a high tensile strength, load-bearing capacity, and resistance to abrasion. Typically, polyurethanes are prepared from polyols and diisocyanates. Lignin possesses aliphatic and phenolic hydroxyl groups, and thus can act as polyol-like material. Saraf and Glasser [154] investigated the characteristics of polyurethane films using pine kraft and aspen steam explosion lignin with hexamethylene isocyanate and tolylene diisocyanate. The properties of the prepared polyurethanes were dependent on the lignins and diisocyanates. While lignin is a polyol polymer, it is also rigid. To improve the mechanical properties of lignin-based polyurethanes, the introduction of soft segments, via the hyroxyalkylations and addition of other polyols, is effective [155-157]. However, high lignin contents were reported to result in rigid and brittle polyurethanes, even with the addition of polyether triols as a third component [158]. Thus the lignin content in lignin-based polyurethanes is usually limited to ca. $30 \%$. Glasser and co-workers showed that hydroxylpropyl lignin-based polyurethanes could be synthesized by mixing PEG as a soft segment. By incorporation of PEG, the $T_{\mathrm{g}}$ decreased, swelling in DMF increased, and the mechanical properties improved as expected [159]. Furthermore, they also investigated the effect of adding polybutadiene glycol on the properties of the prepared the lignin-based polyurethanes [160]. Kraft lignin-containing 
cardanol, which is a natural alkyl phenol from the liquid produced from cashew nut shells, produced flexible polyurethane films with toluene diisocyanate as the long alkyl chain of cardanol can act as a plasticizer [161]. This treatment led to an increase in the lignin content in the polyurethane films up to more than $30 \%$.

Evtuguin et al. [162] used oxygen-organosolv lignins, which were obtained from oxygen pulping in organic solvent-water media, to manufacture lignin-based polyurethanes. The oxygen-organosolv lignins were functionalized with numerous carboxyl and hydroxyl groups [163]; elastomeric polyurethanes could be prepared upon combination with oligoethyleneoxide diisocyanate $\left(M_{\mathrm{n}}=600\right)$ without the addition of any other polyols. The lignin content in polyurethane reached approximately $30 \%$. Chain-extended hydroxypropylated lignin, which was obtained by reaction with propylene oxide, can be also used to produce polyurethane films without any other polyols [164, 165].

Hatakeyama et al. [166] investigated the relationship between lignin content, $\mathrm{NCO} / \mathrm{OH}$ ratio, and mechanical properties in lignin-based polyurethanes. Using softwood kraft lignin, a commercial propylene oxide-based polyether triol, and polymeric methylene diphenyl diisocyanate, they concluded that a low $\mathrm{NCO} / \mathrm{OH}$ ratio $(<1)$ had specific effects on the network formation and influenced the performance of the polyurethane. High kraft lignin contents led to hard and brittle polyurethanes, regardless of the $\mathrm{NCO} /$ $\mathrm{OH}$ ratio.

Usually, polyurethane foams are prepared by the reaction between polyols and diisosyanates with the addition of a surfactant and water. Petroleum-based polyols can be replaced with lignins. Pan and Saddler used hardwood ethanol organosolv lignin and hardwood kraft lignin to replace almost $30 \%$ commercial polyols with the lignins [12]. Addition of another biomass polyol to lignin was investigated. Lignin-based polyurethane foams could be prepared using kraft lignin or lignosulfonate, molasses, PEG with poly(phenylene methylene), or polyisocyanate in the presence of surfactants and a small amount of water [167]. The apparent density, compression strength, and elastic modulus of the polyurethane foams increased with increasing lignin contents. The obtained polyurethane foams exhibited thermal stability up to $300{ }^{\circ} \mathrm{C}$. The polyurethane foams prepared using polyols derived from lignins and molasses displayed water absorbent properties. By adding microcrystalline cellulose, the water absorption rate increased initially and kept larger amount of water over long periods of time [168]. Polyols, except lignin, can affect the mechanical and thermal properties of polyurethane foams. Hatakeyama et al. $[169,170]$ investigated the mechanical and thermal properties of lignin-based polyurethane foams derived from sodium lignosulfonate mixed with diethylene glycol, triethylene glycol, and PEG. The glass transition temperatures and thermal stability increased with decreasing oxyethylene chain lengths, and the compression strength and compression modulus increased with increasing oxyethylene chain lengths.

To produce lignin-based polyurethanes, a two-step reaction system, similar to that used in industrial production, has been applied and involved the synthesis of the prepolymer using isocyanate and a polyol followed by the polymerization of lignin and this pre-polymer. Sarkar and Adhikari [171, 172] prepared prepolymers with hydroxyl terminated polybutadiene and 2,4-toluene diisocyanate with an $\mathrm{NCO} / \mathrm{OH}$ ratio $>1$. Then lignin was reacted with the pre-polymer to obtain lignin-based polyurethane.

In an effort to realize unique polymer properties, interpenetrating polymer networks (IPNs) can be processed. IPNs usually consist of a flexible elastomer and rigid component with a high modulus. This combination may have synergistic effects. Kelley et al. [173] investigated IPNs prepared from lignin-based polyurethanes and poly(methyl methacrylates). The dynamic mechanical thermal analysis of these IPNs revealed two $T_{\mathrm{g}} \mathrm{s}$ for both the lignin-based polyurethane and poly(methyl methacrylate). These $T_{\mathrm{g}} \mathrm{s}$ were far from the $T_{\mathrm{g}} \mathrm{s}$ of the pure components, which indicated partial interactions between the two components. The thermal and mechanical properties varied according to the composition. Huang and Zhang [158] also investigated IPNs using nitro lignin-based polyurethane.

\section{Radical polymerization}

During the 1960s, Koshijima and Muraki conducted the radical grafting of methyl methacrylate [174, 175], styrene [174, 176-178], and vinyl acetate [174] onto hydrochloric acid lignin via radiation with gamma rays in solvent-free systems. Specifically, they investigated potential chemical initiators for the grafting of styrene onto lignin, and concluded that benzoylperoxide was the most effective [179]. They also found that the grafting of methyl methacrylate progressed more effectively than styrene. Moreover, methylation and the addition of a small amount of methanol enhanced the grafting owing to the scavenging effect of the phenolic hydroxyl group and the generation of $\mathrm{H} \cdot$ and $\cdot \mathrm{CH}_{2} \mathrm{OH}$ from methanol by radiolysis. Furthermore, they found that the graft polymerization process proceeded by the addition of polystyrene radicals onto the aromatic nuclei of lignin and propagation proceeded via the branches grafted to the lignin side chain due to the hydrogen abstraction by polymer radicals or primary (initiator) radicals. Phillips et al. [180] also investigated the effect of methylation and the addition of methanol and reported that an increase in the accessibility of styrene affected the 
graft. Softwood kraft lignin could be used for the radiationinduced radical polymerization of styrene. The obtained graft polymer possessed a starting lignin backbone with a low molecular weight and short polystyrene chains, and it could be dissolved in benzene [181].

The polymerization systems mentioned above produced homopolymers as well as graft polymers. In those systems, yields in the order of 25-40 wt\% were common when more than half of the monomer was added to the grafting reaction using styrene [182]. Meister and Chen [183] developed a quantitative graft polymerization system in aprotic, polar organic solvents. They used softwood kraft lignin and dimethyl sulfoxide as the solvent. Hydrogen peroxide and chloride ions were used to prepare poly(lignin- $g$-styrene) in nearly a $100 \%$ grafting efficiency in a high yield (ca. $90 \%$ ) even when the styrene contents were more than $90 \%$.

Solution radical graft polymerization of acrylamide onto softwood kraft lignin upon exposure to a xenon lamp and calcium chloride was carried out in dioxane using hydroperoxidedioxanes prepared from dioxane. The addition of a trace amount of ceric ions promoted the polymerization owing to the production of hydroperoxide radicals. The partially hydrolyzed lignin-acrylamide copolymer was used as an additive in drilling mud [182].

The functionalization of hydroxyl groups is an effective method to facilitate the radical copolymerization of lignin. Notably, to introduce polymerizable groups on the hydroxyl groups, lignin was reacted with chloromethylstyrene or methacryloyl chloride. When up to five moieties were introduced per lignin fragment, a network copolymer was formed owing to the incorporation of the lignin units in the growing chains by means of the polymerizable groups. When the number of polymerizable groups per lignin moiety was as close as possible to one, a linear copolymer was obtained [184]. Other studies showed that lignosulfonate could be used for radical polymerization [185-187].

Recently, atom transfer radical polymerization (ATRP) was applied in the grafting copolymerization of lignin. Kadla and Kim [188] prepared a thermo-responsive copolymer of $\mathrm{N}$-isopropylacrylamide (NIPAM) and hardwood kraft lignin in a DMF/water system. The obtained copolymer possessed a high degree of polymerization of NIPAM (>40) and thermo-responsive characteristics, with a hydrophilic-to-hydrophobic transition at $32{ }^{\circ} \mathrm{C}$. His group also synthesized ionic-responsive lignin-based nanofibers via the ATRP of NIPAM. NIPAM was grafted on soft wood kraft lignin nanofiber prepared by electrospinning with a small amount of polyethylene oxide. The number-average molecular weight and polydispersity of the PNIPAM brushes reached ca. $34 \times 10^{5} \mathrm{Da}$ and 1.22 , respectively. At low salt concentrations (0-0.5 $\left.\mathrm{M} \mathrm{Na}_{2} \mathrm{SO}_{4}\right)$, the surface of the PNIPAM brushes assumed an extended form. However, when the salt concentration was increased $\left(>0.3 \mathrm{M} \mathrm{Na}_{2} \mathrm{SO}_{4}\right)$ the brushes exhibited hydrophobic features, as the surface of the brushes formed a globular contracted chain [189]. Enzymatic ATRP was also developed using catalase, peroxidase, and laccase with ascorbic acid as the reducing agent. When laccase from Trametes versicolor was used, the molecular weight and polydispersity of the obtained PNIPAM brushes were more than $1 \times 10^{5}$ Da and less than 1.3, respectively [190].

\section{Applications of lignin-based materials}

\section{Dispersants}

Lignosulfonate [191-194] was discovered by Scripture and Mark [195]. It is generally used in the cement and concrete industry as a dispersing agent to improve the workability and reduce the water-cement ratio, which results in increased strength. Sulfonated melamine formaldehyde condensate, naphthalene sulfonic acid derivatives, and polycarboxylates are also utilized [196]. Lignosulfonates have a hydrophobic, high molecular weight carbon backbone and hydrophilic moieties, such as sulfonate groups, which result in surface activities. This characteristic property is related to the utilization as a super-plasticizer in concrete and gypsum with excellent dispersing properties. The efficiency can be explained by the hypothesis that the lignosulfonates adsorbed on the particles give rise to repulsive steric and electrostatic forces [197]. The two forces are dependent on the form of the lignosulfonate upon adsorption on the particles [198-200].

Mollah et al. [201, 202] investigated the adsorption mechanism and the effects of lignosulfonate on the hydration of cement by FTIR and X-ray diffraction (XRD). Accordingly, they proposed an adsorption model in which the inner layer forms between $\mathrm{Ca}^{2+}$ and the negatively charged calcium-silica-hydrate $(\mathrm{C}-\mathrm{S}-\mathrm{H})$ surface, while the outer layer, which is composed of lignosulfonate anions, forms concurrently. The adsorption leads to the inhibition of the hydration reaction resulting in the reduction of the formation of $\mathrm{Ca}(\mathrm{OH})_{2}$. Zhang et al. [203] investigated adsorption using zeta potential measurements and proposed a similar model.

The molecular weight of sulfonated compounds significantly affects their performance as dispersants and plasticizers. Previous studies have shown that increasing the molecular weight of sulfonated polymers, including lignosulfonates, obviously improves the dispersion of cement particles, gypsum paste, and coal-water slurries [199, 204, 205]. Stránĕl and Sebök [206, 207] reported that the high molecular weight portions in polydispersed lignosulfonates predominately adsorbed on cement particles. 
To improve the dispersibility of lignosulfonates, the potential to increase the molecular weight of lignosulfonate has been investigated. Zhou et al. [14] reported that the polymerization of lignosulfonates proceeded efficiently upon incubation with horseradish peroxidase $/ \mathrm{H}_{2} \mathrm{O}_{2}$ under mild reaction conditions and the dispersion properties were significantly improved. Ji et al. [200] showed that the dispersive properties of lignosulfonate were improved upon grafting with sulfanilic acid-phenol-formaldehyde condensates, likely because of the high charge density and large steric hindrance.

The relationship between the number of sulfonate groups in lignin and the dispersing efficiency is complicated. Stránĕl and Sebök [208, 209] suggested that the amount of adsorbed lignosulfonates increased with increasing numbers of sulfonate groups. However, with sulfonated lignin prepared from acid hydrolysis lignin, the fluidity of gypsum slurry decreased upon introduction of sulfonate groups. Based on the analysis of the surface tension of an aqueous solution of the sulfonated lignin derived from acid hydrolysis lignin, it was suggested that the amount of the adsorbed sulfonated lignin on the gypsum particles decreased with increasing numbers of sulfonate groups owing to the increased water solubility [198]. From these results, it was concluded that fluidity is dependent on the molecular structure of the lignin, in addition to the molecular weight and charge density [205, 210].

The air content of cement slurry increased upon addition of lignosulfonate. Sebök and Stránĕl [209] implied that the compressive strength of cement increased upon addition of lignosulfonates. However, larger increases in the molecular weight of lignosulfonate led to smaller rises in the strength, possibly because the density decreased when high molecular weight lignosulfonates were added to the cement slurry.

Instead of sulfonate groups, carboxyl groups can be introduced to polymers to generate dispersants [208, 209]. However, lignin with sulfonate groups performed better than that with carboxyl groups.

Polyetherified lignins can be used as non-sulfur containing and non-ionic dispersants. Acetic acid lignin [145] or kraft lignin [148, 149] modified via reaction with several epoxylated PEG derivatives showed high dispersibility. The covalent attachment of amphiphilic polyoxyethylene ether led to a significant improvement in the hydrophilicity of kraft lignin. The prepared dispersant showed high dispersibility and a lower apparent viscosity with $50 \%$ dimethomorph suspension (a kind of agrichemical) as compared to lignosulfonate [150].

Recently, it was reported that soda-anthraquinone lignins from softwood exhibited about two times higher fluidity in mortar than that of commercial lignosulfonate [211]. The high performance soda-anthraquinone lignins had a molecular weight of approximately 4000-5000. Surprisingly, the lignin with a molecular weight of 9000 did not show a high performance. Based on the chemical analysis, the phenolic hydroxyl group content increased in the species with the low molecular weight, suggesting that the balance between the type and content of hydrophilic groups and molecular weight is critical for suitable dispersing efficiencies.

Some grass soda lignins without any chemical modifications were investigated as dispersants and exhibited as a water reducer in mortar [212].

\section{Carbon fibers}

Today, polyacrylonitrile (PAN) serves as a raw material for the manufacturing of carbon fibers (CFs). Coal- and petroleum-derived pitches and regenerated cellulose are also used. One of the characteristic properties of CFs is that they are light weight and strong. Plastics reinforced by CFs possess mechanical performances that are superior to those of plastics reinforced with steel or glass fiber. Moreover, they also have excellent properties with regard to fatigue resistance, dimensional stability and heat resistance, as well as electric conductivity, and electromagnetic interference shielding, which surpass those of other structural materials.

However, the production cost of PAN as a precursor constitutes approximately half of the total production cost of CFs. Due to the high production cost, the use of CFs is limited to specific applications, such as in sporting goods and high-end automotives [213, 214]. Thus lignin is more suitable as a raw material for the production of CFs.

The process used to manufacture CFs using industrial lignin consists of several steps: purification, refining, fiber extrusion, oxidation for stabilization, carbonization, and graphitization. A small-scale pilot plant production of CFs, called Kayacarbon, was developed by Nippon Kayaku Co. during 1967-1973. The fibers were dryspun from an aqueous alkaline solution containing lignin with poly(vinyl alcohol) as a plasticizer. Although the high sodium contents create voids in Kayacarbon fibers as the sodium burned off, the fibers exhibited average performances [215, 216].

Kadla et al. [217] produced CFs for the first time from a commercially available hardwood kraft lignin without any chemical modifications via a thermal pretreatment under vacuum. They reported the effects of blending synthetic polymers such as poly(ethylene oxide) (PEO) [217, 218], poly(ethylene terephthalate) (PET) [219], and polypropylene (PP) [219] as plasticizers into hardwood kraft lignin, and concluded that blending with $5 \%$ PET led to superior mechanical properties [219]. 
On the other hand, the use of softwood kraft lignin is difficult in the production of CFs because it does not soften during heating, but instead is subject to charring. It is wellknown that softwood lignin has a more branched and crosslinked structure than hardwood lignin, which leads to a decreased thermal mobility [220]. Recently, Sjöholm et al. [221-223] manufactured CFs from softwood kraft lignin by blending fractionated hardwood kraft lignin. The fractionated lignin had a low molecular weight and low polydispersity, which enhanced its role as a softening agent. To increase the mobility of the lignins, extracted lignin with organic solvents can be used. The extracted lignin could be spun at a high speed to form a species with a diameter of about $10 \mu \mathrm{m}$ [213].

Lin et al. produced a thermally fusible PEG-lignin, which was obtained directly by the solvolysis of woodchips with a mixture of PEG 400 and sulfuric acid. The PEGlignin could be melt spun at $145-172{ }^{\circ} \mathrm{C}$ without any modifications. The fusibility was found to be dependent on the number of polyethylene moieties. The lignin fiber could subsequently be converted to CFs [152]. To improve the strength of CFs, Lin et al. conducted chemical curing by immersing $\mathrm{CF}$ into a solution of hexamethylenetetramine and hydrochloric acid at $85{ }^{\circ} \mathrm{C}$ for $1 \mathrm{~h}$ to form a methylene bridge between lignin molecules. Consequently, the strength increased 1.5 times [153].

The stabilization step in manufacturing CF involves the transformation of a spun fiber from a thermoplastic to a thermoset character through cross-linking, oxidation, and cyclization reactions. Lignin has a glass transition temperature $\left(T_{\mathrm{g}}\right)$ that is far below the temperatures required for carbonization. Therefore, it must be pretreated to prevent softening. A low heating rate is required to render the lignin fibers infusible. Increasing the thermostabilization temperature at a slow heating rate led to an increase in the $T_{\mathrm{g}}$ as the lignin fibers were maintained in the non-tacky glassy state. Based on kinetic data, Braun predicted that a heating rate of $0.06{ }^{\circ} \mathrm{C} / \mathrm{min}$ or lower was required to maintain $T_{\mathrm{g}}>\mathrm{T}$ during thermostabilization in oxidations under air [224]. Using X-ray photoelectron spectroscopy analysis (XPS) of a cross-section of prepared fibers, Braun et al. [224] reported that the oxidative stabilization of hardwood kraft lignin fibers created a so-called skin-core structure on the fiber that prevented further oxygen penetration into the fiber. The skin-core structure prolonged the stabilization time or hindered the full stabilization of the fibers [221].

The oxidative stabilization of softwood kraft lignin is more facile than that of hardwood kraft lignin. Norberg et al. [225] showed that under oxidative conditions, a heating rate of $15^{\circ} \mathrm{C} / \mathrm{min}$ and $30 \mathrm{~min}$ holding time at $250{ }^{\circ} \mathrm{C}$ was sufficient for the stabilization of softwood kraft lignin. Furthermore, when stabilization and carbonization were conducted via a one-step process on softwood kraft lignin, the production time and costs could be reduced.

To enhance the mechanical properties of CF, copolymerization of hardwood kraft lignin with polyacrylonitrile was attempted [226]. Moreover, to increase the resistance towards thermal degradation, the oxidative pretreatment of kraft lignin with air was proposed [227]. Similar to kraft lignin, acetic acid lignin can be used in the production of CFs. Acetic acid lignin from hardwood lends facilitates the preparation of CFs more so than that from softwood. Hardwood acetic acid lignin could be spun via fusion spinning without any chemical modifications [228], while softwood acetic acid was infusible. The condensed and aryl-ether structure of acetic acid could hinder the thermal mobility [220]. To convert softwood acetic acid lignin into a fusible material, the removal of the high molecular weight fraction or re-cooking with aqueous acetic acid was effective [220, 229]. CFs from softwood acetic acid could be prepared by direct carbonization without thermal stabilization [229]. Thermal hydrogenolysis [230] or phenolysis [231] of steam-exploded lignin from birch was conducted to improve the softening and melting properties. Olganosolv lignin also can be used for the production of CF [232].

\section{Bioactive agents}

Lignosulfonate has been used for many years as an additive in animal feed. The acute and sub-acute oral toxicity of lignosulfonate had been evaluated in rats. Specifically, the acute oral lethal dose for $50 \%\left(\mathrm{LD}_{50}\right)$ was found to be $>40 \mathrm{~g} / \mathrm{kg}$. In sub-acute toxicity tests, no adverse effects on growth, organ weight, or hematology were observed [233]. Recently, the Food and Agricultural Organization of the United Nations (FAO) and the World Health Organization (WHO) reported the approved use of calcium lignosulfonate as a carrier (encapsulating agent) for fat-soluble vitamins, carotenoids, and other functional ingredients in animal feed due to the low toxicity, as the acceptable daily intake is $20 \mathrm{mg} / \mathrm{kg}$ body weight based on a no-effect level of $2000 \mathrm{mg} / \mathrm{kg}$ body weight per day. This information was obtained from a 90-day toxicity study that revealed a safety factor of 100 [234].

Lignosulfonate has several pharmacological effects. Specifically, lignosulfonate was reported to prevent the development of gastric ulcers when administered orally to pyloric-ligated rats. It does not exhibit anti-lipemic effects and results in minimal blood anticoagulation [235]. Lignosulfonate also exhibits biological activities. Notably, it affects a variety of cell-to-cell interactions including fertilization and embryo development in a number of nonmammalian species [236]. Suzuki et al.[237] reported that lignosulfonate exhibits antiviral activities against human 
immunodeficiency virus in vitro. Moreover, Suzuki et al. [238] showed that lignosulfonate could augment glycolysis of macrophages in addition to the proliferation of bone marrow cells. They also reported that water-soluble bagasse lignin extracted from the culture medium of Lentinus edodes mycelia exhibited immunological and antiviral activities. Water-soluble lignin has a highly condensed and polycarboxylated structure [239]. Using a dehydrogenated polymer composed of phenylpropanoids as a model compound, lignin with carboxylic acid moieties exhibited certain biological activities in the studies of stimulating of polymorphonuclear cell iodination [240] and cytopathogenicity of human immunodeficiency virus (HIV) infection [241].

Mitsuhashi et al. [242] reported that low molecular weight high-boiling solvent lignin, which was obtained from olganosolv pulping using aqueous 1,4-butanediol, inhibited human immunodeficiency virus type 1 replication through the suppression of HIV-1 transcription. Using lignin dimer-like models, it was found that compounds with a $\beta-5$ bond possessed more potent inhibitory activities.

Lignosulfonates facilitate the enzymatic saccharification of lignocellulosic materials by the formation of lignosulfonate-cellulase complexes that can mediate the cellulase adsorption between lignin and cellulose [243]. Lignosulfonate fractions with a low molecular weight and a high degree of sulfonation can enhance enzymatic cellulose saccharification. However, an inhibitory effect on saccharification was observed upon using lignosulfonate with a large molecular weight and low degree of sulfonation [244, 245]. Lignosulfonate led to an increase in the phenol oxidase activity of a white-rot fungus, Polyporus dichrous, which is an intracellular tyrosinase-like species [246].

Premjet et al. [247-249] showed that the addition of high molecular weight lignosulfonate could affect the growth of Acetobacter xylinum, resulting in an enhanced bacterial cellulose production and an improvement in crystallinity of the bacterial cellulose. Lignosulfonate also acted as an antioxidant resulting in reduced concentration of gluconic acid [250].

It was also reported that acetic acid lignin derivatives, which react with several epoxylated polyethylene glycol analogs, could act as cellulase-aid agents [143, 251].

\section{Conclusions}

Lignin is the second most abundant organic material on the earth and approximately 70 million tons of technical lignins are generated per year at pulp-making mills. However, nearly all technical lignins are burned to obtain electric power, and only a few percent are used as commercial products [2]. Many researchers have investigated the conversion of lignin into functional materials, but several challenges lead to commercial level. Most of the difficulties regarding the conversion stem from the structural complexity of lignin. Lignin is a polyphenol-based polymer with non-repeating units and the structure varies in different regions of plants such as in the cell wall [252], and is influenced by the environment, for instance the reaction wood, compression wood in softwood and tension wood in hardwood [253, 254]. Unfortunately, lignin cannot be treated in the same manner as homogeneous raw materials such as steel or dissolved pulp.

Technical lignins can be functionalized via various chemical reactions such as esterification, etherification, and urethanization. Such functionalizations may lead to various applications as dispersants, adhesives, plastics, resins, carbon fibers, and bioactive agents among others. However, the production cost of lignin-based materials depends on the type of lignin that is used. Moreover, the quality of the produced materials must be equal to that of commercial products. Further research is required before lignin-based materials can replace commercial products. Towards that end, understanding the characteristics of technical lignins and the creation of new products based on their unique properties are critical for the development of lignin-based materials.

\section{References}

1. Sjöström E (1992) Lignin. Wood chemistry fundamentals and applications, 2nd edn. Academic press, San Diego, pp 71-89

2. Laurichesse S, Avérous L (2014) Chemical modification of lignins: towards biobased polymers. Prog Polym Sci 39:1266-1290

3. Freudenberg K (1959) Biosynthesis and constitution of lignin. Nature 183:1152-1155

4. Hu L, Pan H, Zhou Y, Zhang M (2011) Methods to improve lignin's reactivity as a phenol substitute and as replacement for other phenolic compounds: a brief review. Bioresour 6:1-11

5. Månsson P (1983) Quantitative determination of phenolic and total hydroxy groups in lignins. Holzforschung 37:143-146

6. EI Mansouri NE, Salvadó J (2007) Analytical methods for determining functional groups in various technical lignins. Ind Crop Prod 26:116-124

7. EI Mansouri NE, Salvadó J (2006) Structural characterization of technical lignins for the production of adhesives: application to lignosulfonate, kraft, soda-anthraquinone, organosolv and ethanol process lignin. Ind Crop Prod 24:8-16

8. Ponomarenko J, Dizhbite T, Lauberts M, Viksna A, Dobele G, Bikovens O, Telysheva G (2014) Characterization of softwood and hardwood LignoBoost kraft lignins with emphasis on their antioxidant activity. Bioresources 9:2051-2068

9. West MA, Hickson AC, Mattinen ML, Lloyd-Jones G (2014) Evaluating lignins as enzyme substrates: insights and methodological recommendations from a study of laccase-catalyzed lignin polymerization. Bioresources 9:2782-2796

10. Sjöström E (1992) Wood pulping. Wood chemistry fundamentals and applications, 2nd edn. Academic press, San Diego, pp 114-164 
11. Ekeberg D, Gretland KS, Gustafsson J, Bråten SM, Fredheim GE (2006) Characterisation of lignosulphonates and kraft lignin by hydrophobic interaction chromatography. Anal Chim Acta 565:121-128

12. Pan X, Saddler JN (2013) Effect of replacing polyol by organosolv and kraft lignin on the property and structure of rigid polyurethane foam. Biotechnol Biofuel 6:12-21

13. Alonso MV, Rodríguez JJ, Oliet M, Rodríguez F, García J, Gilarranz MA (2001) Characterization and structural modification of ammonic lignosulfonate by methylolation. J Appl Polym Sci 82:2661-2668

14. Zhou H, Yang D, Qiu X, Wu X, Li Y (2013) A novel and efficient polymerization of lignosulfonates by horseradish peroxidase $/ \mathrm{H}_{2} \mathrm{O}_{2}$ incubation. Appl Microbiol Biotechnol 97:10309-10320

15. Ye DZ, Zhang MH, Gan LL, Li QL, Zhang X (2013) The influence of hydrogen peroxide initiator concentration on the structure of eucalyptus lignosulfonate. Int $\mathrm{J}$ Biol Macromole 60:77-82

16. Sannigrahi P, Ragauskas AJ, Miller SJ (2010) Lignin structural modifications resulting from ethanol organosolv treatment of loblolly pine. Energy Fuel 24:683-689

17. Pan X, Arato C, Gilkes N, Gregg D, Mabee W, Pye K, Xiao Z, Zhang X, Saddler J (2005) Biorefining of softwoods using ethanol organosolv pulping: preliminary evaluation of process streams for manufacture of fuel-grade ethanol and co-products. Biotech Bioeng 90:473-481

18. EI Mansouri NE, Vilaseca J F, Salvadó J (2012) Structural changes in organosolv lignin during its reaction in an alkaline medium. J Appl Polym Sci 126:E213-E220

19. Benar P, Goncçalves AR, Mandelli D, Schuchardt U (1999) Eucalyptus organosolv lignins: study of the hydroxymethylation and use in resol. Bioresour Technol 68:11-16

20. Kin Z (1990) The acetolysis of beech wood. Tappi J 73:237-238

21. Delmas GH, Benjelloun-Mlayah B, Bigot YL, Delmas M (2011) Functionality of wheat straw lignin extracted in organic acid media. J Appl Polym Sci 121:491-501

22. Gellerstedt G, Lindfors EL (1984) Structural changes in lignin during kraft pulping. Holzforschung 38:151-158

23. Mörck R, Yoshida H, Kringstad KP, Hatakeyama H (1986) Fraction of kraft lignin by successive extraction with organic solvents: functional groups, ${ }^{13} \mathrm{C}-\mathrm{NMR}$-spectra and molecular weight distributions. Holzforschung 40(suppl):51-60

24. Nilvebrant NO, Ragauskas A, Dyer T, Kleen M (2001) Ligninextractives-complexes may disturb analysis of isolated lignins by NMR. In: Proceedings of the 11th International Symposium on Wood and Pulping Chemistry, Nice, France, vol 1, pp 139-142

25. Balakshin MY, Capanema EA, Chen AL, Gracz HS (2003) Elucidation of the structures of residual and dissolved pine kraft lignins using an HMQC NMR technique. J Agric Food Chem 51:6116-6127

26. Gierer J, Lindeberg O (1980) Reactions of lignin during sulfate pulping. Part XIX. Isolation and identification of new dimers from a spent sulfate liquor. Acta Chem Scand B34:161-170

27. Berthold F, Gellerstedt G (1993) Reactive structures formed during the initial phase of kraft cook. In: Proceedings of the 7th International Symposium on Wood and Pulping Chemistry, Beijing, China, vol 3, pp 160-163

28. Gierer J, Norén I, Wännström S (1987) Formation of condensation products on treatment of nom-phenolic lignin units of the $\beta$-aryl ether type with alkali. Model studies on a novel mode of alkaline lignin condensation. Holzforschung 41:79-82

29. Kringstad K, Mörck R (1983) ${ }^{13}$ C-NMR spectra of kraft lignins. Holzforschung 37:237-244
30. Capanema EA, Balakshin MY, Chen CL, Gratzl JS, Gracz H (2001) Structural of residual and technical lignins by ${ }^{1} \mathrm{H}^{13} \mathrm{C}$ correlation 2D NMR-spectroscopy. Holzforschung 54:302-308

31. Sipilä J, Wiik C, Koli K, Filpponen I, Karhunen P, Maunu SL, Liitiä T (2001) Mordan NMR techniques and model experiments in search for changes in the chemical structure of lignin during pulping. In: Proceedings of the 11th International Symposium on Wood and Pulping Chemistry, Nice, France, vol 1, pp 9-12

32. Terashima N, Araki H, Suganuma N (1977) Radiotracer experiments on lignin reactions II: the behavior of lignin in kraft pulping process (in Japanese). Mokuzai Gakkaishi 23:343-347

33. Niemelä K, Alén R, Sjöström E (1985) The formation of carboxylic acids during kraft and kraft-anthraquinone pulping of birch wood. Holzforschung 39:167-172

34. Löwendahl L, Peterson G, Sanuelson O (1978) Phenolic compounds in kraft black liquor. Svensk Papperstidn 81:392-396

35. Niemelä K, Sjöström E (1985) Identification of $\alpha$-hydroxy-syringylalkanoic acids in birch kraft black liquors. Holzforschung 39:365-366

36. Gierer J, Wännström S (1984) Formation of alkali-stable C-C bonds between lignin and carbohydrate fragments during kraft pulping. Holzforschung 38:181-184

37. Gierer J, Wännström S (1986) Formation of ether bonds between lignin and carbohydrates during alkaline pulping process. Holzforschung 40:347-352

38. Westermark U, Samuelsson B, Lundquist K (1995) Homolytic cleavage of the $\beta$-ester bond in phenolic $\beta-O-4$ structures in wood lignin and in guaiacylglycerol- $\beta$-guaiacyl ether. Res Chem Intermed 21:343-352

39. Tsutsumi Y, Kondo R, Imamura H (1993) Reaction of syringylglycerol- $\beta$-syringyl ether type of lignin model compounds in alkaline medium. J Wood Chem Technol 13:25-42

40. Sipilä J, Brunow G, Ämmälahti E, Kilpeläinen I, Bujanovic B, Hortling B (1999) On the chemical structure of lignins in situ and in pulps revealed by multidimensional NMR studies. In: Proceedings of the 10th international symposium on wood and pulping chemistry, Yokohama, Japan, vol 1, pp 364-367

41. Sipilä J, Brunow G, Tunninen P, Niemi T, Åhlgren A (1997) Degradation of quinone methides via $\beta$-ether hemolysis-An important reaction the chemistry of hardwood lignins? In: Proceedings of the 9th International Symposium on Wood and Pulping Chemistry, Montreal, Canada, Oral, pp B2-1-B2-4

42. Mortimer RD (1982) The formation of coniferyl alcohol during alkaline delignification with anthraquinone. J Wood Chem Technol 2:383-415

43. Kondo R, McCarthy JL (1985) Condensation of lignins with coniferyl alcohol in alkaline aqueous solutions. J Wood Chem Technol 5:37-52

44. Taneda H, Nakano J, Hosoya S, Chang HM (1987) Stability of $\alpha$-ether type model compounds during chemical pulping processes. J Wood Chem Technol 7:485-498

45. Lindberg JJ, Tylli H, Majani C (1964) Notes on the molecular weight and the fractionation of lignins with organic solvents. Paperi Puu 46:521-526

46. Helm RF, Toikka M, Li K, Brunow G (1997) Lignin model glycosides: preparation and optical resolution. J Chem Soc Perkin Trans 1(1997):533-537

47. Goliath M, Lindgren BO (1961) Reactions of thiosulphate during sulphite cooking. Part 2. Mechanism of thiosulfate sulphidation of vanillyl alcohol. Svensk Papperstidning 64:469-471

48. Gierer J (1970) The reactions of linin during pulping. Adescription and comparison of conventional pulping process. Svensk Papperstidning 73:571-596

49. Gellerstedt G, Gierer J (1971) The reactions of lignin during acidic sulphite pulping. Svensk Papperstidning 74:117-127 
50. Glennie DW (1971) Reactions in sulfite pulping. In: Sarkanen $\mathrm{KV}$, Ludwig $\mathrm{CH}$ (eds) Lignins occurrence, formation, structure and reactions. Wiley Interscience, New York, pp 597-694

51. Meshitsuka G, Nakano J (1972) Studies on double bonds in lignosulphonate: existence of chalcone structure in lignosulphonate. Pulp Paper Mag Can 73:61-64

52. Brudin S, Schoenmakers P (2010) Analytical methodology for sulfonated lignins. J Sep Sci 33:439-452

53. Araki H, Kachi S, Terashima N (1977) Radiotracer experiments on lignin reactions III: the behavior of lignin in acidic sulfite pulping process (in Japanese). Mokuzai Gakkaishi 23:348-352

54. Sakakibara A (1980) A structure model of softwood lignin. Wood Sci Technol 14:89-100

55. Lutnaes BF, Myrvold BO, Lauten RA, Endeshaw MM (2008) ${ }^{1} \mathrm{H}$ and ${ }^{13} \mathrm{C}$ NMR data of benzylsulfonic acids-model compounds for lignosulfonate. Magn Reson Chem 46:299-305

56. Gardon JL, Mason SG (1955) Physicochemical studies of lignosulphonates II: behavior as polyelectrolytes. Can J Chem 33:1491-1501

57. Rezanowich A, Goring DAI (1960) Polyelectrolyte expansion of a lignin sulfonate microgel. J Colloid Sci 15:452-471

58. Goring DAI (1971) Polymer properties of lignin and lignin derivatives. In: Sakanen KV, Ludwig CH (eds) Lignins, occurrence, formation, structure and reactions. Wiley Interscience, New York, pp 695-768

59. Kontturi AK, Kontturi A, Niinikoski P (1991) Transport of lignosulphonates under an external electric field. J Chem Soc Faraday Trans 87:1779-1783

60. Myrvold BO (2008) A new model for the structure of lignosulphonates. Part 1. Behaviour in dilute solutions. Ind Crop Prod 27:214-219

61. Pye EK, Lora JH (1991) The Alcell ${ }^{\mathrm{TM}}$ process. A proven alternative to kraft pulping. Tappi J 74:113-118

62. Sarkanen KV (1990) Chemistry of solvent pulping. Tappi J 73(10):215-219

63. Shimada K, Hosoya S, Ikeda T (1997) Condensation reactions of softwood and hardwood lignin model compounds under organic acid cooking conditions. J Wood Chem Technol 17:57-72

64. Liu Y, Carriero S, Pye K, Argyropoulos DS (2000) A comparison of the structural changes occurring in lignin during Alcell and kraft pulping of hardwoods and softwoods. In: Grasser WG, Norhey RA, Schultz TP (eds) ACS Symposium Series 742 Lignin: historical, biological, and materials perspectives. American Chemical Society, Washington, DC, pp 447-464

65. Young RA, Davis JL (1986) Organic acid pulping of wood. Part II. Acetic acid pulping of aspen. Holzforschung 40:99-108

66. Davis JL, Young RA, Deodhar SS (1986) Organic acid pulping of wood III. Acetic acid pulping of spruce. Mokuzai Gakkaishi 32:905-914

67. Sano Y, Maeda H, Sakashita Y (1989) Pulping of wood at atmospheric pressure I: pulping of hardwoods with aqueous acetic acid containing a small amount of organic sulfonic acid. Mokuzai Gakkaishi 35:991-995

68. Sano Y, Nakamura M, Shimamoto S (1990) Pulping of wood at atmospheric pressure II: pulping of birch of wood with aqueous acetic acid containing a small amount of sulfuric acid. Mokuzai Gakkaishi 36:207-211

69. Parajó JC, Alonso JL, Vázquez D (1993) On the behavior of lignin and hemicelluloses during the acetosolv processing of wood. Bioresour Technol 46:233-240

70. Shukry N, Fadel SM, Agblevor FA, EI-Kalyoubi SF (2008) Some physical properties of acetosolv lignins from bagasse. J Appl Poly Sci 109:434-444

71. Davis JL, Nakatsubo F, Murakami K, Umezawa T (1987) Organic acid pulping of wood IV: reactions of arylglycerol- $\beta$ guaiacyl ethers. Mokuzai Gakkaishi 33:478-486
72. Yasuda S, Ito N (1987) Behavior of lignin in organic acid pulping I: reaction of arylglycerol- $\beta$-aryl ethers with acetic acid. Mokuzai Gakkaishi 33:708-715

73. Yasuda S (1988) Behavior of lignin in organic acid pulping II: reaction of phenylcoumaran and 1,2-diaryl-1,3-propanediol with acetic acid. J Wood Chem Technol 8:155-164

74. Erismann NM, Freer J, Baeza J, Durán N (1994) Organosolv pulping VII: delignification selectivity of formic acid pulping of Eucalyptus grandis. Bioresour Technol 47:247-256

75. Forss KG, Fuhrmann A (1979) Finnish plywood, particleboard, and fireboard made with a lignin-base adhesive. Forest Prod J 29:39-43

76. Forss FG, Fuhrmann A (1976) KARATEX-the lignin-based adhesive for plywood, particle board and fibre board. Pap Puu 58:817-824

77. Marton J, Marton T, Falkchag SI, Adler E (1966) Alkali-catalyzed reactions of formaldehyde with lignins. In: Marton J (ed) Lignin structure and reactions., Advances in Chemistry Series 59American Chemical Society, Washington, DC, pp 125-144

78. Zhao LW, Griggs BF, Chen CL, Gratzl JS (1994) Utilization of softwood kraft lignin as adhesive for the manufacture of reconstituted wood. J Wood Chem Technol 14:127-145

79. Gupta RC, Sehgal VC (1979) Effect of viscosity and molecular weight of lignin-phenolformaldehyde resin on the glue adhesion strength of plywood. Holzforsch Holzverwert 31:7-9

80. Klašnja B, Kopitovič S (1992) Lignin-phenol-formaldehyde resins as adhesives in the production of plywood. Holz Roh Werkst 50:282-285

81. Kazayawako JSM, Riedle B, Poiquin J, Barry AO, Matuana LM (1992) A lignin-phenol-formaldehyde binder for particle board. Part 1. Thermal characteristics. Holzforschung 46:257-262

82. Moubarik A, Grimi N, Boussetta N, Pizzi A (2013) Isolation and characterization of lignin from Moroccan sugar cane bagasse: production of Phenol-formaldehyde wood adhesives. Ind Crop Prod 45:296-302

83. Hamidreza S, Fan GM (2014) Lignin in straw and its applications as an adhesive. Int $\mathbf{J}$ Adhes Adhes 48:92-101

84. Peng W, Riedl B, Barry O (1993) Study on the kinetics of lignin methylolation. J Appl Polym Sci 48:1757-1763

85. Budin D, Suša L, Volčič J (1990) Application of modified lignosulfonates ini adhesives for insulation board manufacture based mineral wool. J Wood Chem Technol 10:531-542

86. Ayla VC (1982) Properties and decomposition of lignins isolated by means of an alcoholic-water-mixture VII: utilization of ethanol-water lignins as a glue for wood. Holzforschung 36:93-98

87. Vázquez G, Antorrena G, González J, Mayor J (1995) Ligninphenol-formaldehyde adhesives for exterior grade plywoods. Bioresour Technol 51:187-192

88. Vázquez G, González J, Freire S, Antorrena G (1997) Effect of chemical modification of lignin on the glue bond performance of lignin-phenol resins. Bioresour Technol 60:191-198

89. Sano Y, Ichikawa A (1987) Preparation of lignin-based phenol resin adhesives from solvolysis lignins. Mokuzai Gakkaishi 33:42-46

90. Sano Y, Yamane N (1987) Preparation of lignin-based resorcinol resin adhesives from solvolysis lignins. Mokuzai Gakkaishi 33:47-52

91. Dolenko AJ, Clarke MR (1978) Resin binders from kraft lignin. For Prod J 28:41-47

92. Alonso MV, Oliet M, Rodríguez F, Astarloa G, Echeverría JM (2004) Use of a methylolated softwood ammonium lignosulfonate as partial substitute of phenolin resol resins manufacture. J Appl Polym Sci 94:643-650

93. Malutan T, Nicu R, Popa VI (2008) Contribution to the study of hydroxymethylation reaction of alkali lignin. BioResour 3:13-20 
94. Nimz H (1969) Condensation reactions of lignin. Reaction of lignin model compounds with resorcinol and hydrochloric acid. Holzforschung 23:84-88

95. Kratzl K, Oburger M (1980) Condensation reactions of lignin model compounds with phenol under acid catalysis. Holzforschung 34:11-16

96. Kratzl K, Oburger M (1980) Condensation reactions of lignin model compounds with phenol under acid catalysis. Part II. Holzforschung 34:191-196

97. Funaoka M, Abe I (1987) Phenyl nucleus-exchange method for the degradation of lignin. Wood Sci Technol 21:261-279

98. Yasuda S, Tachi M, Takagi Y (1989) Phenolization of red pine sulfuric acid lignin and guaiacyl sulfuric acid lignin model in the presence of sulfuric acid catalyst. Mokuzai Gakkaishi 35:513-520

99. Funaoka M, Fukatsu S (1996) Characteristics of lignin structural conversion in a phase-separative reaction system composed of cresol and sulfuric acid. Holzforschung 50:245-252

100. Lin L, Yao Y, Shiraishi N (2001) Liquefaction mechanism of $\beta$ $O-4$ lignin model compound in the presence of phenol under acid catalysis. Holzforschung 55:617-624

101. Gierer J, Pettersson I (1977) Studies on the condensation of lignins in alkaline media. Part II. The formation of stilbene and arylcoumaran structures through neighbouring group participation reactions. Can J Chem 55:593-599

102. Gierer J, Lindeberg O (1979) Studies on the condensation of lignins in alkaline media. Part III. The formation of stilbenes, aryl coumarins and diaryl methanes on treatment of spruce wood meal with alkali and white liquor in the presence of xylenols. Acta Chem Scand B33:580-622

103. Kabayashi A, Haga T, Sato K (1966) On the reaction of thiolignin with phenol (in Japanese). Mokuzai Gakkaishi 12:305-310

104. Kabayashi A, Haga T, Sato K (1967) On the properties of tholignin modified with phenol as a raw material of phenolic resin (in Japanese). Mokuzai Gakkaishi 13:306-312

105. Kabayashi A, Haga T, Sato K (1967) On the reaction between phenol modified thiolignin and hexamethylenetetramine (in Japanese). Mokuzai Gakkaishi 13:312-318

106. Shashi JSP, Singh SV, Gupta RC (1982) Kinetics and mechanism of lignin formaldehyde resinification reaction. Cellul Chem Technol 16:511-522

107. Hayashi A, Nakamura Y, Urkita T (1967) Demethylation of lignosulphonate during the gelling reaction with dichromate. Mokuzai Gakkaishi 13:194-197

108. Olivares M, Guzmán JA, Natho A, Saavedra A (1988) Kraft lignin utilization in adhesives. Wood Sci Technol 22:157-165

109. Gupta RC, Singh SP, Shashi J (1978) Phenol-formaldehyde adhesives for plywood. Holzforsch Holzverwet 30:6-9

110. An XN (1995) Demethylated kraft lignin as a substitute for phenol in wood adhesive. Chem Ind Forest Prod 15:36-42

111. Wu S, Zhen H (2001) Characteristics of demethylated wheat straw soda lignin and its utilization in lignin-based phenolic formaldehyde resins. Cellul Chem Technol 35:253-262

112. Lundquist K (2001) Lignin reactions in neutral, acidic and alkaline media. In: Proceedings of the 11th International Symposium on Wood and Pulping Chemistry, Nice, France, vol 1, pp 1-4

113. Matsushita Y, Jo EK, Inakoshi R, Yagami S, Takamoto N, Fukushima K, Lee SC (2013) Hydrothermal reaction of sulfuric acid lignin generated as a by-product during bioethanol production using lignocellulosic materials to convert bioactive agents. Ind Crop Prod 42:181-188

114. Chen CM (1995) Gluability of kraft lignin copolymer resins on bonding southern pine plywood. Holzforschung 49:153-157

115. Cheng S, Yuan Z, Leitch M, Anderson M, Xu CC (2013) Highly efficiency de-polymerization of organosolve lignin using a catalytic hydrothermal process and production of phenolic resin/ adhesives with the depolymerized lignin as a substitute for phenol a high substitution ratio. Ind Crop Prod 44:315-322

116. Shintani K, Sano Y, Sasaya T (1994) Preparation of moderatetemperature setting adhesives from softwood kraft lignin. Holzforschung 48:337-342

117. Shintani K, Sano Y (1995) Preparation of kraft lignin-based cold-setting wood adhesives. Holzforschung 49:351-357

118. Auad ML, Zhao L, Shen H, Nutt SR, Sorathia U (2007) Flammability properties and mechanical performance of epoxy modified phenolic foams. J Appl Polym Sci 104:1399-1407

119. Hu L, Zhou Y, Zhang M, Liu R (2012) Characterization and properties of a lignosulfonate-based phenolic foam. Bioresour 7:554-564

120. Hu L, Zhou Y, Liu R, Zhang M, Yang X (2013) Synthesis of foaming resol resin modified with oxidatively degraded lignosulfonate. Ind Crop Prod 44:364-366

121. Koch VH, Krause F, Steffan R, Woelk HU (1983) Herstellung von Phenolharzen unter Verwendung von Stärkeprodukten. Starch/Stärke 35:304-313

122. Zhang L, Zheng Y, Zhang Y, Lin T (2013) Effect of starch and lignin on physico-chemical properties of phenol-starch resin and its resin core sand. Starch/Stärke 65:666-678

123. Oliveira W, Glasser WG (1994) Multiphase Materials with lignin. 11. Starlike copolymers with caprolactone. Macromolecules 27:5-11

124. Hirose S, Hatakeyama T, Izuta Y, Hatakeyama H (2002) TGFTIR studies on lignin-based polycaprolactones. J Therm Anal Calorimetry 70:853-860

125. Matsushita Y, Inomata T, Takagi Y, Hasegawa T, Fukushima K (2011) Conversion of sulfuric acid lignin generated during bioethanol production from lignocellulosic materials into polyesters with $\varepsilon$-caprolactone. J Wood Sci 57:214-218

126. Matsushita Y, Inomata T, Hasegawa T, Fukushima K (2009) Solubilization and functionalization of sulfuric acid lignin generated during bioethanol production from woody biomass. Bioresour Technol 100:1024-1026

127. Chung YL, Olsson JV, Li RJ, Frank CW, Waymouth RM, Billington SL, Sattely ES (2013) A renewable lignin-lactide copolymer and application in biobased composites. ACS Sustain Chem Eng 1:1231-1238

128. Guo ZX, Gandini A, Pla F (1992) Polyesters from lignin. 1: the reaction of kraft lignin with dicarboxylic acid chlorides. Polym Int 27:17-22

129. Guo ZX, Gandini A (1991) Polyesters from lignin-2. The copolyesterification of kraft lignin and polyethylene glycols with dicarboxylic acid chlorides. Eur Polym J 27:1177-1180

130. Luong ND, Binh NTT, Duong LD, Kim DO, Kim DS, Lee SH, Kim BJ, Lee YS, Nam JD (2012) An eco-friendly and efficient route of lignin extraction from black liquor and a llignin-based copolyester synthesis. Polym Bull 68:879-890

131. Fang R, Cheng XS, Lin WS (2011) Preparation and application of dimer acid/lignin graft copolymer. Bioresour 6:2874-2884

132. Saito T, Brown RH, Hunt MA, Pickel DL, Pickel JM, Messman JM, Baker FS, Keller M, Naskar AK (2012) Turning renewable resources into value-added polymer: development of ligninbased thermoplastic. Green Chem 14:3295-3303

133. Sivasankarapillai G, McDonald AG (2011) Synthesis and properties of lignin-highly brached poly(ester-amine) polymeric systems. Biomass Bioenergy 35:919-931

134. Sivasankarapillai G, McDonald AG, Li H (2012) Lignin valorization by forming toughened lignin-co-polymers: development of hyperbranched prepolymers for cross-linking. Biomass Bioenergy 47:99-108

135. Hirose S, Hatakeyama T, Hatakeyama H (2005) Curing and glass transition of epoxy resins from ester-carboxylic acid 
derivatives of mono-and disaccharides, and alcoholysis lignin. Macromol Symp 224:343-353

136. Ismal TNMT, Hassan HA, Hirose S, Taguchi Y, Hatakeyama T, Hatakeyama H (2010) Synthesis and thermal properties of estertype crosslinked epoxy resins derived from lignosulfonate and glycerol. Polym Int 59:181-186

137. Ahvazi B, Wojciechwicz O, Ton-That TM, Hawari J (2011) Preparation of lignopolyols from wheat straw soda lignin. J Agric Food Chem 59:10505-10516

138. Hatakeyama T, Izuta Y, Hirose S, Hatakeyama H (2002) Phase transition of lignin-based polycaprolactones and their polyurethane derivatives. Polymer 43:1177-1182

139. Hofmann K, Glasser WG (1993) Engineering plastics from lignin. 21. Synthesis and properties of epoxidized ligninpoly(propylene oxide) copolymers. J Wood Chem Technol 13:73-95

140. Simionescu CI, Cazacu G, Macoveanu MM (1987) Lignin-epoxy resins II: physical and chemical characterization. Cellul Chem Technol 21:525-534

141. Simionescu CI, Rusan V, Turta KI, Bobcova SA, Macoveanu MM, Cazacu G (1993) Synthesis and characterization of some iron-lignosulfonate-base epoxy resins. Cellul Chem Technol 27:627-644

142. Zhao B, Chen G, Liu Y, Hu K, Wu R (2001) Synthesis of lignin base epoxy resin and its characterization. J Matt Sci Lett 20:859-862

143. Uraki Y, Ishikawa N, Nishida M, Sano Y (2001) Preparation of amphiphilic lignin derivative as a cellulase stabilizer. J Wood Sci 47:301-307

144. Nishida M, Uraki Y, Sano Y (2003) Lignin gel with unique swelling property. Bioresour Technol 88:81-83

145. Homma H, Kubo S, Yamada T, Matsushita Y, Uraki Y (2008) Preparation and characterization of amphiphilic lignin derivatives as surfactants. J Wood Chem Technol 28:270-282

146. Delmas GH, Benjelloun-Mlayah B, Bigot YL, Delmas M (2013) Biolignin $^{\mathrm{TM}}$ based epoxy resins. J Appl Polym Sci 127: 1863-1972

147. Nonaka Y, Tomita B, Hatano Y (1997) Synthesis of lignin/ epoxy resins in aqueous systems and their properties. Holzforschung 51:183-187

148. Homma H, Kubo S, Yamada T, Koda K, Matsushita Y, Uraki Y (2010) Conversion of technical lignins to amphiphilic derivatives with high surface activity. J Wood Chem Technol 30:164-174

149. Aso T, Koda K, Kubo S, Yamada T, Nakajima I, Uraki Y (2013) Preparation of novel lignin-based cement dispersants from isolated lignins. J Wood Chem Technol 33:286-298

150. Lin X, Zhou M, Wang S, Lou H, Yang D, Qiu X (2014) Synthesis, structure, and dispersion property of novel lignin-based polyoxyethylene ether from kraft lignin and poly(ethylene glycol). ACS Sustain Chem Eng 2:1902-1909

151. Kubo S, Yamada T, Hashida K, Ono H (2007) Grafting of ethylene glycol chains in lignin during the solvolysis for biomass conversion using ethylene carbonate/ethylene glycol system. Chem Lett 36:502-503

152. Lin J, Kubo S, Yamada T, Koda K, Uraki Y (2012) Chemical thermostabilization for the preparation of carbon fibers from softwood lignin. BioResources 7:5634-5646

153. Lin J, Koda K, Kubo S, Yamada T, Enoki M, Uraki Y (2014) Improvement of mechanical properties of softwood lignin-based carbon fibers. J Wood Chem Technol 34:111-121

154. Saraf VP, Glasser WG (1984) Engineering plastics from lignin III: structure property relationships in solution cast polyurethane films. J Appl Polym Sci 29:1831-1841

155. Wu LCF, Glasser WG (1984) Engineering plastics from lignin I: synthesis of hydroxypropyl lignin. J Appl Polym Sci 29:1111-1123
156. Glasser WG, Barnett CA, Rials TG, Saraf VP (1984) Engineering plastics from lignin II: characterization of hydroxylalkyl lignin derivatives. J Appl Polym Sci 29:1815-1830

157. Nadji H, Bruzzèse C, Belgacem MN, Benaboura A, Gandini A (2005) Oxypropylation of lignins and preparation of rigid polyurethane foams from the ensuing polyols. Macromol Mater Eng 290:1009-1016

158. Huang J, Zhang L (2002) Effects of $\mathrm{NCO} / \mathrm{OH}$ molar ratio on structure and properties of graft-interpenetrating polymer networks from polyurethane and nitrolignin. Polymer 43:2287-2294

159. Saraf VP, Glasser WG, Wilkes GL, McGrath JE (1985) Engineering plastics from lignin VI: property relationships of PEGcontaining polyurethane networks. J Appl Polym Sci 30:2207-2224

160. Saraf VP, Glasser WG, Wilkes GL (1985) Engineering plastics from lignin VII: structure property relationships of poly(butadiene glycol)-containing polyurethane networks. J Appl Polym Sci 30:3809-3823

161. Tan TTM (1996) Cardanol-lignin-based polyurethanes. Polym Int 41:13-16

162. Evtuguin DV, Andreolety JP, Gandini A (1998) Polyurethanes based on oxygen-organosolv lignin. Eur Polym J 34:1163-1169

163. Zarubin YM, Deineko IP, Evtuguin DV, Robert A (1989) Delignification by oxygen in acetone-water media. Tappi $\mathrm{J}$ 72:163168

164. Kelly SS, Glasser WG, Ward TC (1988) Engineering plastics from lignin XIV: characterization of chain-extended hydroxypropyl lignins. J Wood Chem Technol 8:341-359

165. Kelly SS, Glasser WG, Ward TC (1988) Engineering plastics from lignin $\mathrm{XV}$ : polyurethane films from chain-extended hydroxypropyl lignin. J Appl Polym Sci 36:759-772

166. Yoshida H, Mörck R, Kringstad KP, Hatakeyama H (1987) Kraft lignin in polyurethanes I: mechanical properties on polyurethanes from a kraft lignin-polyether triol polymeric MDI system. J Appl Polym Sci 24:1187-1198

167. Hatakeyama H, Hatakeyama T (2005) Environmentally compatible hybrid-type polyurethane foams containing saccharide and lignin components. Macromol Symp 224:219-226

168. Hatakeyama H, Kato N, Nanbo T, Hatakeyama T (2012) Water absorbent polyurethane composites derived from molasses and lignin filled with microcrystalline cellulose. J Mater Sci 47:7254-7261

169. Hatakeyama T, Asano Y, Hatakeyama H (2003) Mechanical and thermal properties of rigid polyurethane foams derived from sodium lignosulfonate mixed with diethlene-, triethylene- and polyethylene glycols. Macromol Symp 197:171-180

170. Asano Y, Hatakeyama H, Hatakeyama T (2003) Thermal and mechanical properties of sodium lignosulfonate-based rigid polyurethane foams prepared with three kinds of polyols. Sen'i Gakkaishi 59:465-470

171. Sarkar S, Adhikari B (2001) Synthesis and characterization of lignin-HTPB copolyurethane. Eur Polym J 37:1391-1401

172. Sarkar S, Adhikari B (2001) Thermal stability of lignin-hydroxy-terminated polybutadiene copolyurethanes. Polym Degrad Stab 73:169-175

173. Kelly SS, Ward TC, Glasser WG (1990) Multiphase materials with lignin VIII: interpenetrating polymer networks from polyurethanes and polymethyl methacrylate. J Appl Polym Sci 41:2813-2828

174. Koshijima T, Muraki E (1964) Radiation grafting of methyl methacrylate onto lignin (in Japanese). Mokuzai Gakkaishi 10:110-115

175. Koshijima T, Muraki E (1964) Degradation of lignin-methy methacrylate graft copolymer by $\gamma$-ray irradiation (in Japanese). Mokuzai Gakkaishi 10:116-119 
176. Koshijima T, Muraki E (1966) Solvent effects upon radicalinduced graft copolymerization of styrene onto lignin (in Japanese). Mokuzai Gakkaishi 12:139-144

177. Koshijima T (1966) Oxidation of lignin-stylene graftpolymer. Mokuzai Gakkaishi 12:144-150

178. Koshijima T, Muraki E (1968) Radical grafting on lignin. Part 1. Radiation-induced grafting of Styrene onto hydrochloric acid lignin. J Polym Sci Part A-1 6:1431-1440

179. Koshijima T, Muraki E (1967) Radical grafting on lignin II: grafting of styrene onto lignin by initiators. Mokuzai Gakkaishi 13:355-359

180. Phillips PB, Brown W, Stannett VT (1971) The graft copolymerization of stylene and lignin I: hydrochloric acid lignin. J Appl Polym Sci 15:2929-2940

181. Phillips PB, Brown W, Stannett VT (1972) The graft copolymerization of styrene and lignin II: kraft softwood lignin. J Appl Polym Sci 16:1-14

182. Meister JJ, Patil DR (1984) Properties and applications of lignin-acrylamide graft copolymer. J Appl Polym Sci 29:3457-3477

183. Meister JJ, Chen MJ (1991) Graft 1-phenylethlene copolymers of lignin. 1. Synthesis and proof of copolymerization. Macromolecule 24:6843-6848

184. Cunha CD, Deffieux A, Fontanille M (1993) Synthesis and polymerization of lignin-based macromonomers III: radical copolymerization of lignin-based macromonomers with methy methacrylate. J Appl Polym Sci 48:819-831

185. Nam C, Koshijima T, Muraki E, Maku T (1971) Graft copolymerization of methyl methacrylate onto lignosulfonate by $\mathrm{H} 2 \mathrm{O} 2-\mathrm{Fe}(\mathrm{II})$ redox system I: preparation and characterization of the graft copolymer. J Polym Sci Part A-1 9:855-866

186. Chen R, Kokta BV, Valade JL (1979) Graft copolymerization of lignosulfonate and styrene. J Appl Polym Sci 24:1609-1618

187. Chen R, Kokta BV, Valade JL (1980) Study on the graft copolymerization of lignosulfonate and acrylic monomers. J Appl Polym Sci 25:2211-2220

188. Kim YS, Kadla JF (2010) Preparation of a thermoresponsive lignin-base biomaterial through atom transfer radical polymerization. Biomactomolecule 11:981-988

189. Gao G, Dallmeyer JI, Kadla JF (2012) Synthesis of lignin nanofibers with ionic-responsive shells: water-expandable lignin-based nanofibrous mats. Biomacromolecule 13:3602-3610

190. Gao G, Karaaslan MA, Kadla JF, Ko F (2014) Enzymatic synthesis of ionic responsive lignin nanofibers through surface poly $(N$-isopropylacrylamide) immobilization. Green Chem 16:3890-3898

191. Scripture ED Jr (1937) Indurating composition for concrete. US Patent 2,081,642

192. Scripture ED Jr (1938) Hardening and waterproofing composition for concrete or mortar. US Patent 2,127,451

193. Scripture ED Jr (1939) Cement mix. US Patent 2,169,980

194. Scripture ED Jr (1941) Cement composition. US Pat 2(229):311

195. Mark JG (1938) Concrete and hydraulic cement. US Patent 2,141,570

196. Ernsberger FM, France WG (1945) Portland cement dispersion by adsorption of calcium lignosulfonate. Ind Eng Chem 37:596-600

197. Uchikawa H, Hanehara S, Sawaki D (1997) The role of steric repulsive force in the dispersion of cement particles in fresh paste prepared with organic admixture. Cem Concr Res 27:37-50

198. Matsushita Y, Imai M, Iwatsuki A, Fukushima K (2008) The relationship between surface tension and the industrial performance of water-soluble polymers prepared from acid hydrolysis lignin, a saccharification by-product from woody materials. Bioresour Technol 99:3024-3028

199. Lou H, JiK Lin H, PangY Deng Y, QiuX Zhang H, Xie Z (2012) Effect of molecular weight of sulphonated acetone- formaldehyde condensate on its adsorption and dispersion properties in cementitious system. Cem Concr Res 42:1043-1048

200. Ji D, Luo Z, He M, Shi Y, Gu X (2012) Effect of both grafting and blending modifications on the performance of lignosulphonate-modified sulphanilic acid-phenol-formaldehyde condensates. Cem Concr Res 42:1199-1206

201. Mollah MYA, Palta P, Hess TR, Vempati RK, Cocke DL (1995) Chemical and physical effects of sodium lignosulfonate superplasticizer on the hydration of Portland cement and solidification/stabilization consequences. Cem Concr Res 25:671-682

202. Mollah MYA, Yu W, Schennach R, Cocke DL (2000) A fourier transform infrared spectroscopic investigation of the early hydration of Portland cement and the influence of sodium lignosulfonate. Cem Concr Res 30:267-273

203. Zhang T, Shang S, Yin F, Aishah A, Salmiah A, Ooi TL (2001) Adsorptive behavior of surfactants on surface of Portland cement. Cem Concr Res 31:1009-1015

204. Matsushita Y, Yasuda S (2005) Preparation and evaluation of lignosulfonates as a dispersant for gypsum paste from acid hydrolysis lignin. Bioresour Technol 96:465-470

205. Yang D, Qiu X, Zhou M, Lou H (2007) Properties of sodium lignosulfonate as dispersant of coal water slurry. Energy Convers Manag 48:2433-2438

206. Stránĕl O, Sebök T (1997) Relationships between the properties of ligninsulphonates and parameters of modified samples with cement binders. Part I. Characterizing ligninsulphonates and studying their sorption properties. Cem Concr Res 27:185-191

207. Sebök T, Stránĕl O (1999) Relationships between the properties of lignosulphonates and parameters of modified samples with cement binders. Part II. Study of relationships between molar parameters of lignosulphonates and characteristics of the samples tested. Cem Concr Res 29:591-594

208. Stránĕl O, Sebök T (1999) Relationships between the properties of ligninsulphonates and prameters of modified samples with cement binders. Part III. Determination of sulphonated compounds content, characteristic of sulphonation, sorption studies. Cem Concr Res 29:1769-1772

209. Sebök T, Stránĕl O (2000) Relationships between the properties of ligninsulphonates and parameters of modified samples with cement binders. Part IV. Influence of sulphonated compounds and sulphonation characteristics on the properties of mortar samples. Cem Concr Res 30:511-515

210. Shandra S, Björnström J (2002) Influence of cement and superplasticizers type and dosage on the fluidity of cement mortars-Part I. Cem Concr Res 32:1605-1611

211. Takahashi S, Hattori M, Morimoto M, Uraki Y, Yamada T (2014) Performance of softwood soda-anthraquinone lignin as water-reducing chemical admixture in concrete. J Wood Chem Technol 34:31-38

212. Nadif A, Hunkeler D, Käuper P (2002) Sulfur-free lignins from alkaline pulping tested in mortar for use as mortar additives. Bioresour Technol 84:49-55

213. Baker DA, Gallego NC, Baker FS (2012) On the characterization and spinning of an organic-purified lignin toward the manufacture of low-cost carbon fiber. J Appl Polym Sci 124:227-234

214. Baker DA, Rials TG (2013) Recent advances in low-cost carbon fiber manufacture from lignin. J Appl Polym Sci 130:713-728

215. Tomizuka I, Kurita T, Tanaka Y, Watanabe O (1971) Voids in the carbon fibers produced from lignin and PVA. Yogyo-Kyokai-Shi 79:460-469

216. Johnson DJ, Tomizuka I, Watanabe O (1975) The fine structure of lignin-based carbons. Carbon 13:321-325

217. Kadla JF, Kubo S, Venditti RA, Gilbert RD, Compere AL, Griffith W (2002) Lignin-based carbon fibers for composite fiber applications. Carbon 40:2913-2920 
218. Kubo S, Kadla JF (2005) Kraft lignin/poly(ethylene oxide) blends: effect of lignin structure on miscibility and hydrogen bonding. J Appl Polym Sci 98:1437-1444

219. Kubo S, Kadla JF (2005) Lignin-based carbon fibers: effect of synthetic polymer blending on fiber properties. J Polym Environ 13:97-105

220. Kubo S, Ishikawa N, Uraki Y, Sano Y (1997) Preparation of lignin fibers from softwood acetic acid lignin: relationship between fusibility and the chemical structure of lignin. Mokuzai Gakkaishi 43:655-662

221. Brodin I, Ernstsson M, Gellerstedt G, Sjöholm E (2012) Oxidative stabilisation of kraft lignin for carbon fibre production. Holzforschung 66:141-147

222. Nordström Y, Norberg I, Sjöholm E, Drougge R (2013) A new softening agent for melt spinning of softwood kraft lignin. J Appl Polym Sci 129:1274-1279

223. Nordström Y, Joffe R, Sjöholm E (2013) Mechanical characterization and application of weibull statistics to the strength of softwood lignin-based carbon fibers. J Appl Polym Sci 130:3689-3697

224. Braun JL, Holtman KM, Kadla JF (2005) Lignin-based carbon fibers: oxidative thermostabilization of kraft lignin. Carbon 43:385-394

225. Norberg I, Nordström Y, Drougge R, Gellerstedt G, Sjöholm E (2012) A new method for stabilizing softwood kraft lignin fibers for carbon fiber production. J Appl Polym Sci 128:3824-3830

226. Maradur SP, Kim CH, Kim SY, Kim BH, Kim WC, Yang KS (2012) Preparation of carbon fibers from a lignin copolymer with polyacrylonitrile. Synth Met 162:453-459

227. Brodin I, Sjöholm E, Gellerstedt G (2010) The behavior of kraft lignin during thermal treatment. J Anal Appl Pyrolysis 87:70-77

228. Uraki Y, Kubo S, Nigo N, Sano Y, Sasaya T (1995) Preparation of carbon fibers from organbosolv lignin obtained by aqueous acetic acid pulping. Holzforschung 49:343-350

229. Kubo S, Uraki Y, Sano Y (1998) Pretreatment of carbon fibers from softwood lignin by atmospheric acetic acid pulping. Carbon 36:1119-1124

230. Sudo K, Shimizu K (1992) A new carbon fiber from lignin. J Appl Polym Sci 44:127-134

231. Sudo K, Shimizu K, Nakashima N, Yokoyama A (1993) A new modification method of exploded lignin for the preparation of a carbon fiber precursor. J Appl Polym Sci 48:1485-1491

232. Foston M, Nunnery GA, Meng X, Sun Q, Baker FS, Ragauskas A (2013) NMR a critical tool to study the production of carbon fiber from lignin. Carbon 52:65-73

233. Luscombe DK, Nicholls PJ (1973) Acute and subacute oral toxicity of AHR-2438B, a purified sodium lignosulphonate, in rats. Food Cosmet Toxicol 11:229-237

234. Anonymous (2008) Summary and conclusion of the 69th meeting of Joint FAO/WHO Expert Committee on Food Additives, Food and Agricultural Organization of United Nations and World Health Organization, Rome, Italy

235. Vocac JA, Alphin RS (1968) Effects and mechanism of action of a lignosulphonate on experimental gastric ulceration in rats. Eur J Pharmcol 4:99-102

236. Tollner TL, Overstreet JW, Li MW, Meyers SA, Yudin AI, Salinas ER, Cherr GN (2002) Lignosulfonic acid blocks in vitro fertilization of macaque oocytes when sperm are treated either before or after capacitation. J Andrology 23:889-898

237. Suzuki H, Tochikura TS, Iiyama K, Yamazaki S, Yamamoto N, Toda S (1989) Lignosulfonate, a water-solubilized lignin from the waste liquor of the pulping process, inhibits the infectivity and cytopathic effects of human immunodeficiency virus in vitro. Agric Biol Chem 53:3369-3372

238. Suzuki H, Iiyama K, Okubo A, Yamazaki S, Toda S (1989) Lignosulfonate from waste liquor of pulping process activates murine macrophages and causes proliferation of bone marrow cells. Agric Biol Chem 53:1197-1199

239. Suzuki H, Iiyama K, Yoshida O, Yamazaki S, Yamamoto N (1990) Structural characterization of immunoactive and antiviral water-solubilized lignin in an extract of the culture medium of Lentinus edodes mycelia (LEM). Agric Biol Chem $54: 479-487$

240. Sakagami H, Oh-hara T, Kohda K, Kawazoe Y (1991) Lignified materials as a potential medicinal resource. IV. Dehydrogenation polymers of some phenylpropanoids and their capacity to stimulate polymorphonuclear cell iodination. Chem Pharm Bull 39:950-955

241. Nakashima H, Murakami T, Yamamoto N, Naoe T, Kawazoe Y, Konno K, Sakagami H (1992) Lignified materials as a potential medicinal resource V: aniti-HIV (human immunodeficiency virus) activity of some synthetic lignins. Chem Pharm Bull 40:2102-2105

242. Mitsuhashi S, Kishimoto T, Uraki Y, Okamoto T, Ubukata M (2008) Low molecular weight lignin suppresses activation of NF- $\kappa \mathrm{B}$ and HIV-1 promoter. Bioorgan Med Chem $16: 2645-2650$

243. Wang Z, Zhu JY, Fu Y, Qin M, Shao Z, Jiang J, Yang F (2013) Lignosulfonate-mediated cellulase adsorption enhanced enzymatic saccharification of lignocellulose through weakening nonproductive binding to lignin. Biotechnol Biofuel 6:156-165

244. Zhou H, Lou H, Yang D, Zhu JY, Qiu X (2013) Lignosulfonate to enhance enzymatic saccharification of lignocelluloses: role of molecular weight and substrate lignin. Ind Eng Chem Res 52:8464-8470

245. Lou H, Zhou H, Li X, Wang M, Zhu JY, Qiu X (2014) Understanding the effects of lignosulfonate on enzymatic saccharification of pure cellulose. Cellulose 21:1351-1359

246. Räihä M, Sundman V (1975) Characterization of lignosulfonateinduced phenol oxidase activity in the atypical white-rot fungus Polyporus dichrous. Arch Microbiol 105:73-76

247. Premjet S, Ohtani Y, Sameshima K (1994) Bacterial cellulose production by Acetobacer xylinum ATCC 10245 in a new culture medium with a sulfite pulping waste fraction. Sen-i Gakkaishi 50:124-128

248. Premjet S, Ohtani Y, Sameshima K (1994) The contribution of high molecular lignosulfonate to the powerful bacterial cellulose production system with Acetobacter xylinum ATCC 10245. Seni Gakkaishi 50:458-463

249. Premjet S, Ohtani Y, Sameshima K (1996) X-ray diffraction diagram of the bacterial cellulose membrane produced by Acetobacter xylinum in the medium with lignosulfonate. Sen-i Gakkaishi 52:169-174

250. Keshk S, Sameshima K (2006) Influence of lignosulfonate on crystal structure and productivity of bacterial cellulose in a static culture. Enzym Microbial Technol 40:4-8

251. Bardant TB, Oikawa C, Nojiri M, Koda K, Sudiyani Y, Yamada T, Uraki Y (2010) Improvement of saccharification of empty fruit bunch and Japanese cedar pulps with an amphiphilic lignin derivative (in Japanese). Mokuzai Gakkaishi 56:420-426

252. Fukushima K, Terashima N (1991) Heterogeneity in formation of lignin 14 Formation and structure of ligninin differentiating xylem of Ginko biloba. Holzforschung 45(Apr):87-94

253. Sarkanen KV, Hergert HL (1971) Classification and distribution. In: Sarkanen KV, Ludwig CH (eds) Lignins: occurrence, formationstructure and reactions. Wiley-Interscience, New York, pp 43-94

254. Fukushima K, Terashima N (1991) Heterogeneity in formation of lignin. 15. Formation and structure of lignin in compression wood of Pinus thunbergii studied by microautoradiography. J Wood Sci Technol 25:371-381 